\title{
Characterization of exosomal release in bovine endometrial intercaruncular stromal cells
}

Yong Qin Koh, Hassendrini N. Peiris, Kanchan Vaswani, Sarah Reed, Gregory E. Rice, Carlos Salomon and Murray D. Mitchell

\begin{abstract}
Background: Cell-to-cell communication between the blastocyst and endometrium is critical for implantation. In recent years, evidence has emerged from studies in humans and several other animal species that exosomes are secreted from the endometrium and trophoblast cells and may play an important role in cell-to-cell communication maternal-fetal interface during early pregnancy. Exosomes are stable extracellular lipid bilayer vesicles that encapsulate proteins, miRNAs, and mRNAs, with the ability to deliver their cargo to near and distant sites, altering cellular function(s). Furthermore, the exosomal cargo can be altered in response to environmental cues (e.g. hypoxia). The current study aims to develop an in vitro system to evaluate maternal-embryo interactions via exosomes (and exosomal cargo) produced by bovine endometrial stromal cells (ICAR) using hypoxia as a known stimulus associated with the release of exosomes and alterations to biological responses (e.g. cell proliferation).
\end{abstract}

Methods: ICAR cells cultured under $8 \% \mathrm{O}_{2}$ or $1 \% \mathrm{O}_{2}$ for $48 \mathrm{~h}$ and changes in cell function (i.e. migration, proliferation and apoptosis) were evaluated. Exosome release was determined following the isolation (via differential centrifugation) and characterization of exosomes from ICAR cell-conditioned media. Exosomal proteomic content was evaluated by mass spectrometry.

Results: Under hypoxic conditions (i.e. $1 \% \mathrm{O}_{2}$ ), ICAR cell migration and proliferation was decreased ( 20 and $\sim 32 \%$, respectively) and apoptotic protein caspase-3 activation was increased ( $\sim 1.6$ fold). Hypoxia increased exosome number by $\sim 3.6$ fold compared with culture at $8 \% \mathrm{O}_{2}$. Mass spectrometry analysis identified 128 proteins unique to exosomes of ICAR cultured at $1 \% \mathrm{O}_{2}$ compared with only 46 proteins unique to those of ICAR cultured at $8 \% \mathrm{O}_{2}$. Differential production of proteins associated with specific biological processes and molecular functions were identified, most notably ADAM10, pantetheinase and kininogen 2.

Conclusions: In summary, we have shown that a stimulus such as hypoxia can alter both the cellular function and exosome release of ICAR cells. Alterations to exosome release and exosomal content in response to stimuli may play a crucial role in maternal-fetal crosstalk and could also affect placental development.

Keywords: Bovine, Intercaruncular, Hypoxia, Exosomes

\footnotetext{
* Correspondence: murray.mitchell@uq.edu.au

University of Queensland Centre for Clinical Research, The University of

Queensland, Brisbane, Queensland, Australia
} 


\section{Background}

In dairy cattle, the average gestation length is approximately 282 days. The placenta is epitheliochorial, cotyledonary and non-deciduate [1]. Placentation is restricted to the aglandular maternal caruncles, where the fetal cotyledons come into contact with each other [2, 3]. They then form the placentome for maternal-fetal exchange of oxygen, nutrients and waste products. The glandular intercaruncular regions are associated with preserving the uterus in a state of quiescence and allowing a progressive uterine hypertrophy to accommodate the increasing needs of the growing feto-placental unit [4]. The uterine glands present in the intercaruncular endometrial areas secrete and release histotroph that is crucial for conceptus survival and growth [5] and is transported into the fetal circulation via the placental areolae. The establishment of a successful pregnancy requires the interactions between the endometrial cells and the early conceptus during maternal recognition of pregnancy $[6,7]$.

Cells located within intercaruncular region and associated with maternal fetal crosstalk include cells of stromal (intercaruncular stromal cell; ICAR) and epithelial origin. Both cell types are known to produce prostaglandins (e.g. $\mathrm{PGF}_{2 \alpha}$ ) and have immunomodulatory functions [8, 9]. Interactions between these cells may also play a pivotal role in endometrial receptivity during early pregnancy as was reported in a co-culture study that human endometrial stromal cells can mediate epithelial cell function by promoting differentiation and inhibiting proliferation of endometrial epithelial cells [10]. In the bovine, endometrial stromal cells (as utilized in the current study) are known to differentially regulate the production of prostaglandins and enzymes related to the production of prostaglandins, in response to specific stimuli (e.g. inflammatory mediators and interferon tau) $[8,11]$. ICAR cells were a kind gift from Professor Michel A. Fortier (Université Laval, Québec). ICAR cells are a transformed cell-line derived from the intercaruncular region of the bovine endometrium [12]. ICAR cells can be propagated while still maintaining the phenotypical characteristics of these cells which include the presence of SV40 TAG and the vimentin-positive and cytokeratinnegative features that support the stromal phenotype of these cells $[8,13]$. This study aimed to evaluate the effect of a known stimulus of exosome release on the production of exosomes by ICAR cells.

In recent years, evidence has emerged from studies in humans [14] and several other animal species [15-18] that exosomes are secreted from the endometrium and trophoblast cells and may play important roles at the conceptus-endometrial interface during early pregnancy. Exosomes are specific subsets of extracellular vesicles (smaller than $1000 \mathrm{~nm}$ ) [19] that could provide insights into an alternative new explanation for the crosstalk between cells. Exosomes (30-120 nm) are stable extracellular lipid bilayer vesicles arising from the inward budding of multivesicular bodies and released via an exocytic pathway to the extracellular environment with the capacity to modify the biological function of target cells [20]. Exosomes provide a mechanism of cell-to-cell communication in physiological and pathological conditions and may be influenced by neighboring cells, distant tissues or local environmental factors. There is considerable evidence that hypoxia is a potent stimulant to the release of exosomes [21-24]. It is also a useful investigatory agent since a lower-than-normal oxygen tension in utero can influence many developmental events with potentially lifelong consequences [25, 26].

Hypoxia is a well-known stimulus of exosome release as seen in breast cancer cells, endothelial cells and human trophoblasts [24, 27, 28]. Alterations have been documented in both the number of exosomes released as well as differences in the content (cargo) of the exosomes $[24,27,29]$. This study aimed to test the hypothesis that hypoxia as a known stimulus of exosome release (and altered biological response) will modify the phenotype of bovine endometrial stromal cells affecting their migration, proliferation, apoptosis as well as altering both the release and cargo of the exosomes generated.

\section{Methods}

Aim

This study investigated the effect(s) of a hypoxic environment on the function of bovine endometrial cells. In particular, alterations to migration, proliferation and apoptosis. Moreover, this study evaluated alterations to the release and cargo content of exosomes generated by bovine endometrial cells, when cultured under hypoxia.

\section{Endometrial cell line}

A well characterized bovine endometrial intercaruncular stromal cell line (ICAR cells) was utilized for the current study $[8,30]$. ICAR cells were a kind gift from Professor Michel A. Fortier (Université Laval, Québec). ICAR cells were maintained in $175 \mathrm{~cm}^{2}$ (T175, Corning Costar) culture flasks supplemented with exosome-free media (1640 Roswell Park Memorial Institute (RPMI) medium (Invitrogen, Life Technologies) with $10 \%$ heat-inactivated fetal bovine serum (Bovogen, Interpath services Pty Ltd) depleted of exosomes by ultracentrifugation $(100,000 \mathrm{~g}$ for $20 \mathrm{~h}$ at $4{ }^{\circ} \mathrm{C}$ ) and $1000 \mathrm{U} / \mathrm{mL}$ antibiotic-antimycotic solution (Gibco, Life Technologies) in a humidified cell culture incubator at $37{ }^{\circ} \mathrm{C}$ under an atmosphere of $5 \%$ $\mathrm{CO}_{2}$-balanced $\mathrm{N}_{2}$ to obtain a hypoxic $\left(1 \% \mathrm{O}_{2}\right)$ environment or under physiologically relevant conditions (8\% $\left.\mathrm{O}_{2}\right)$. Lactate dehydrogenase $(\mathrm{LDH})$ assay was also 
performed accordingly to the manufacturer's protocol using the commercially available kit Pierce LDH cytotoxicity assay kit (Thermo scientific) to measure LDH in supernatants of ICAR cells cultured at $8 \% \mathrm{O}_{2}$ and $1 \% \mathrm{O}_{2}$ and ICAR cell viability was accessed. No significant difference in the LDH activity was observed (data not shown) between $8 \% \mathrm{O}_{2}$ and $1 \% \mathrm{O}_{2}$, indicating that the viability of ICAR cells was not affected by experimental condition.

\section{Cell migration assay}

The effect of oxygen tension on cell migration was assessed using methods as previously published [31]. Briefly, ICAR cells were plated (30,000 cells per well) and grown to confluence in a 96-well culture plate (Corning Costar) at $1 \% \mathrm{O}_{2}$ or $8 \% \mathrm{O}_{2}$ oxygen tension and a wound scratch was made on confluent monolayers using a 96-pin WoundMaker (Essen BioScience). Migration assays were performed in the presence of Mitomycin C (100 ng/mL, Sigma-Aldrich) to minimize any confounding effects of cell proliferation. The wound images were automatically acquired every $2 \mathrm{~h}$ for $48 \mathrm{~h}$ and registered by the IncuCyte software system (Essen BioScience). Data are presented as the Relative Wound Density (RWD, Eizen, v1.0 algorithm). RWD is a representation of the spatial cell density in the wound area relative to the spatial cell density outside of the wound area at every time point (time-curve).

\section{Cell proliferation assay}

Proliferation of ICAR cells was assessed using methods as previously published $[28,31]$. In brief, the effect of oxygen tension on ICAR cell proliferation was assessed using a non-labelled cell monolayer confluence approach with a high density phase contrast real-time cell imaging system (IncuCyte ${ }^{\mathrm{rx}}$ ). ICAR cells were seeded at 40,000 cells per well in a 12-well culture plate (Corning Costar) and exposed to oxygen tension at $1 \% \mathrm{O}_{2}$ or $8 \% \mathrm{O}_{2}$ and the cell confluence (as the proliferation parameter) was measured at 0,24 and $48 \mathrm{~h}$.

\section{Cell apoptosis assay}

To assess the effect of hypoxia on cell apoptosis, ICAR cells were seeded at 5000 cells per well in 96-well culture plate (Corning Costar) in the presence of CellPlayer Kinetic Caspase-3/7 Apoptosis Assay Reagent (1:5000; Essen Biosciences) and imaged at $48 \mathrm{~h}$ with IncuCyte ${ }^{\mathrm{im}}$. Cell apoptosis is determined by the measurement of the number of activated caspase 3/7 fluorescent objects count per $\mathrm{mm} 2$ divided by the percentage of cell confluence at $48 \mathrm{~h}$ (percentage of the area of field of view covered by cells with the metric 'phase object confluence') with the IncuCyte Zoom software using an integrated object counting algorithm.

\section{Exosome isolation from cell-conditioned media}

To study the effect of oxygen tension on exosome release, ICAR cells were incubated at $1 \% \mathrm{O}_{2}$ or $8 \% \mathrm{O}_{2}$ for $48 \mathrm{~h}$. Exosomes were isolated from ICAR cell culture-conditioned media by successive differential centrifugation steps at $300 \times g$ for $10 \mathrm{~min}$ and $2000 \times g$ for $30 \mathrm{~min}$. The supernatant was filtered through a $0.22-\mu \mathrm{m}$ filter (Corning Costar) and ultracentrifuged at 100,000 $\times g$ for $20 \mathrm{~h}$ at $4{ }^{\circ} \mathrm{C}$ (Sorvall, SureSpin 630/360, Swingingbucket ultracentrifuge rotor). Another round of ultracentrifugation washing steps was performed at 100,000 $\times g$ for $2 \mathrm{~h}$ at $4{ }^{\circ} \mathrm{C}$ (Beckman, Type $70.1 \mathrm{Ti}$, Fixed angle ultracentrifuge rotor). Exosomes were further enriched by layering on top of a discontinuous iodixanol gradient (OptiPrep, Sigma-Aldrich), which was centrifuged at $100,000 \times g$ for 20 h (Beckman, Sw41Ti, Swinging-bucket ultracentrifuge rotor). Twelve fractions were obtained and diluted in $10 \mathrm{~mL}$ PBS (Gibco, Life Technologies). The fractions were washed with $\mathrm{PBS}$ and centrifuge at $100,000 \times g$ for $2 \mathrm{~h}$ (Beckman, Type $70.1 \mathrm{Ti}$, Fixed angle ultracentrifuge rotor) and the exosomal pellets were suspended in $50 \mu \mathrm{L}$ PBS.

\section{Nanoparticle Tracking Analysis (NTA)}

NTA measurements were performed using a NanoSight NS500 instrument (NanoSight NTA 3.0 Nanoparticle Tracking and Analysis Release Version Build 0064) as previously described [32, 33].

\section{Western blot analysis and transmission electron microscopy}

Exosomes were solubilized in RIPA buffer (Sigma-Aldrich) and separated by polyacrylamide gel electrophoresis, transferred to a polyvinylidene fluoride (PVDF) membrane (Bio-Rad) and probed with primary rabbit polyclonal antibody anti-CD63 (1:1000; EXOAB-CD63A1, System Biosciences) and TSG101 (1:500; sc-6037, Santa Cruz Biotechnology). For electron microscopy analysis, exosome pellets were fixed in $3 \%(\mathrm{w} / \mathrm{v})$ glutaraldehyde and analyzed under an FEI Tecnai 12 transmission electron microscope (FEI, Hillsboro, Oregon, USA).

\section{Proteomic Analysis of Endometrial Exosomes by Mass Spectrometry (MS)}

Exosomes $(10 \mu \mathrm{g}$ of protein) were solubilized in RIPA buffer (Sigma-Aldrich) and separated by polyacrylamide gel electrophoresis. The gel was fixed in fixing solution (10:1:9; ethanol, acetic acid, MilliQ water respectively) for $15 \mathrm{~min}$, washed in (1:1, ethanol and MilliQ water) for $10 \mathrm{~min}$ and washed three times with MilliQ water. Proteins were stained with Coomassie Brilliant Blue R250 staining solution (Bio-Rad) for $1 \mathrm{~h}$ and the gel was allowed to destain in MilliQ water until a clear background was obtained. 
In-gel digestion methods for the mass spectrometric identification of exosomal proteins were performed by modification of previously published method [34]. In brief, each sample lane was cut into 24 gel slices and destained twice with $200 \mathrm{mM}$ ammonium bicarbonate in $50 \%$ acetonitrile solution for $45 \mathrm{~min}$ at $37{ }^{\circ} \mathrm{C}$, desiccated using a vacuum centrifuge and then resuspended with $20 \mathrm{mM}$ dithiothreitol (DTT) in $25 \mathrm{mM}$ ammonium bicarbonate solution and reduced for $1 \mathrm{~h}$ at $65{ }^{\circ} \mathrm{C}$. DTT was then removed, and the samples were alkylated in $50 \mathrm{mM}$ iodoacetamide and $25 \mathrm{mM}$ ammonium bicarbonate at $37{ }^{\circ} \mathrm{C}$ in darkness for $40 \mathrm{~min}$. Gel slices were washed three times for $45 \mathrm{~min}$ in $25 \mathrm{mM}$ ammonium bicarbonate and then desiccated. Individual dried slices were then allowed to swell in $20 \mu \mathrm{L}$ of $40 \mathrm{mM}$ ammonium bicarbonate, $10 \%$ acetonitrile containing $20 \mu \mathrm{g} / \mathrm{mL}$ trypsin (Sigma) for $1 \mathrm{~h}$ at room temperature. An additional $50 \mu \mathrm{L}$ of the same solution was added and the samples were incubated overnight at $37^{\circ} \mathrm{C}$.

The supernatants were removed from the gel slices, and residual peptides were washed from the slices by incubating them three times in $50 \mu \mathrm{L}$ of $0.1 \%$ formic acid for $45 \mathrm{~min}$ at $37{ }^{\circ} \mathrm{C}$. The original supernatant and washes were combined and desalted according to a modified version of the stage tip protocol that we have published [35, 36] using a 3-mm piece of an Empore C18 (Octadecyl) SPE Extraction Disk and the eluted peptides were dried in a vacuum centrifuge prior to spectral acquisition.

The digested protein samples were analysed using the TripleTOF 5600 mass spectrometer (ABSciex, Redwood City, CA) and Eksigent 1D+ NanoLC system with the cHiPLC system to obtain initial high mass accuracy survey MS/MS data, identifying the peptides present in the samples. The ChromXP C18-CL TRAP cHiPLC $(200 \mu \mathrm{m} \times 6 \mathrm{~mm}, 3 \mu \mathrm{m}, 120 \AA)$ and analytical cHiPLC columns $(200 \mu \mathrm{m} \times 15 \mathrm{~cm} ; 3 \mu \mathrm{m}, 120 \AA)$ (Eksigent, Redwood City, CA) were used to separate the digested proteins. A $10 \mu \mathrm{L}$ aliquot of digested material was injected onto the column and separated with a linear gradient of 5 to $10 \%$ Buffer B for 2 min (Buffer A: $0.1 \%$ Formic acid/water; Buffer B: acetonitrile $/ 0.1 \%$ formic acid), 10 to $40 \%$ Buffer B (58 min), 40 to $50 \%$ Buffer B (10 min), 50 to $95 \%$ $(10 \mathrm{~min})$ with a flow rate of $500 \mathrm{~nL} / \mathrm{min}$. The column was flushed at $95 \%$ buffer B for $15 \mathrm{~min}$ and reequilibrated with $5 \%$ Buffer B for 6 min. The in-depth proteomic analysis was performed using the Information Dependent Acquisition (IDA) experiments on the TripleTOF $^{\bullet} 5600$ System interfaced with a nanospray source. The source parameters were as follows: Cur gas at $25 \mathrm{psi}$, GS1 at 5 psi and IHT at $150{ }^{\circ} \mathrm{C}$. A $250 \mathrm{msec}$ accumulation time was set for the TOFMS survey scan and from this scan, the 10 most intense precursor ions were selected automatically for the MS/MS analysis (accumulation time of 150 msecs per MS/MS scan). Ions were isolated using unit resolution of the quadrupoles and rolling collision energy equation was used to calculate the collision energies of precursors. The precursor selection criteria included a minimum intensity of 50 counts per second (cps) and a charge state greater than $2+$.

Protein identification was determined using the ProteinPilot $^{\text {tw }}$ Software (v4.5 beta, AB Sciex, Redwood City, $\mathrm{CA}$ ) with the Paragon algorithm. The search parameters were as follows: sample type, identification; cys alkylation, iodoacetamide; digestion, Trypsin; Instrument, TripleTOF 5600; special factors, none; and ID focus, biological modifications. The database was downloaded from the UniProt website in October 2015, which contained all proteins from Bos taurus. False discovery rate (FDR) was selected in the method and determined using a reversed sequence database. Data were subjected to ontology and pathway analysis using the protein analysis through evolutionary relationships tool (PANTHER) and gene ontology algorithms and classified based on biological process and molecular function categories [37].

\section{Statistical analyses}

The effects of oxygen tensions on ICAR cells are presented as mean \pm SE for migration, proliferation and apoptosis assays $(n=6$ independent experiments in duplicate). The number of exosomes is presented as number of particles per $\mathrm{mL}$ (mean $\pm \mathrm{SE}, n=3$ independent isolations from 80 million cells each). The effects of oxygen tension on ICAR cells were identified by Student's $\mathrm{T}$ tests (two-tailed) to compare the effect of hypoxia (i.e. $1 \% \mathrm{O}_{2}$ ) with the control group (i.e. $8 \% \mathrm{O}_{2}$ ) using a commercially-available software package (Prism 6, GraphPad Inc, La Jolla, CA 92037 USA).

\section{Results \\ The Effect of Oxygen Tension on Bovine Endometrial (ICAR) cell migration and proliferation}

The effect of normal oxygen tension (i.e. $8 \% \mathrm{O}_{2}$ ) and hypoxia (i.e. $1 \% \mathrm{O}_{2}$ ) on ICAR cell migration is presented in Fig. 1. ICAR cell migration was significantly lower under hypoxia compared with normal oxygen tension (Fig. 1a). Hypoxia decreased ICAR cell migration in a time-dependent manner (Fig. 1b). Area under the curve analysis indicated that hypoxia decreased ICAR cell migration by $\sim 20 \%$ compared with values observed at $8 \% \mathrm{O}_{2}\left(2173 \pm 36\right.$ and $2620 \pm 50$ for $1 \% \mathrm{O}_{2}$ and $8 \%$ $\mathrm{O}_{2}$, respectively) (Fig. 1c). Interestingly, hypoxia decreased ICAR cell proliferation in a time-dependent manner (Fig. 2a and b). Area under curve analysis showed that at $1 \% \mathrm{O}_{2}$, the proliferative capacity of ICAR cells was inhibited $(p<0.05) \sim 32 \%$ compared with 

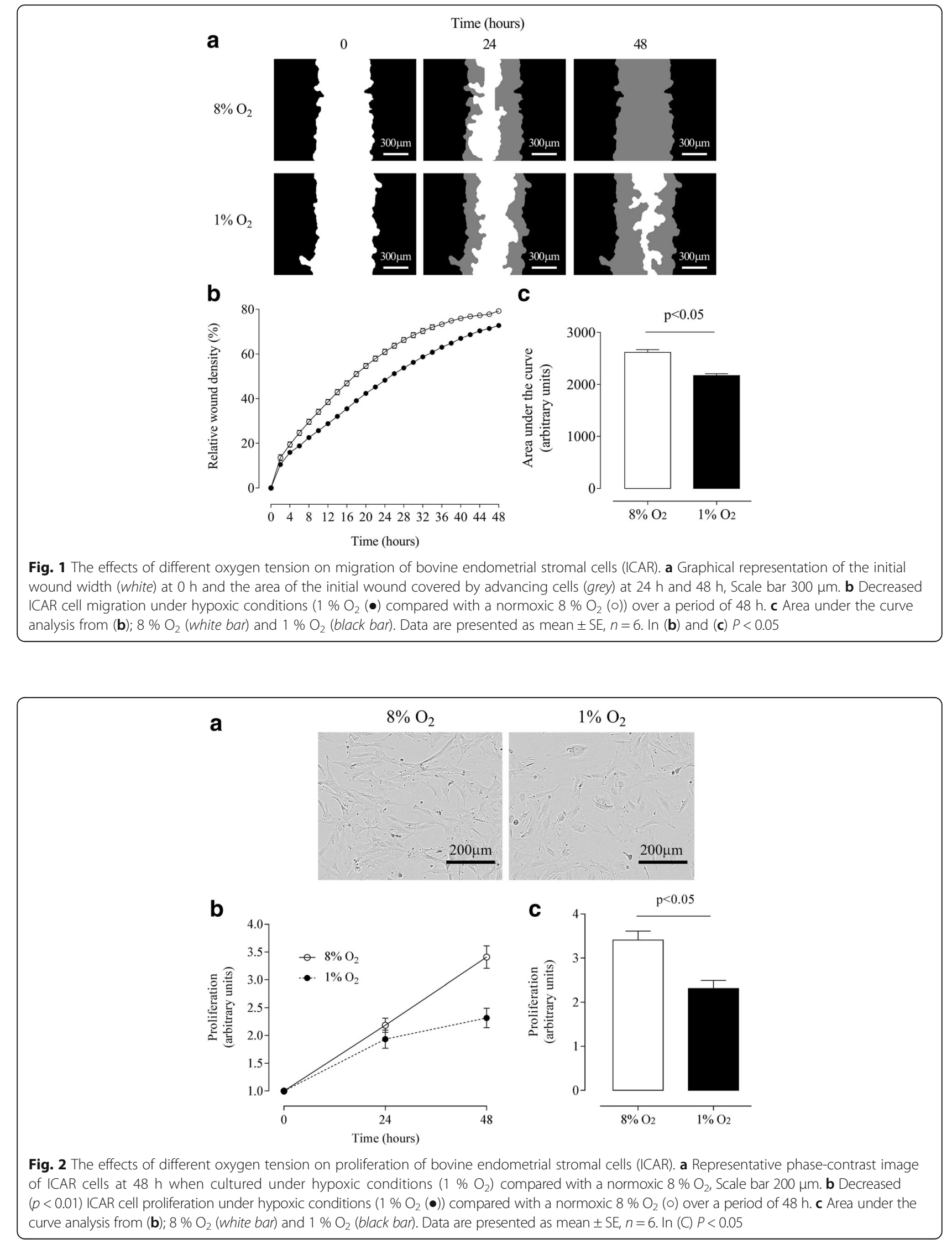
cell proliferation at $8 \% \mathrm{O}_{2}(2.32 \pm 0.18$ and $3.41 \pm 0.2$ for $1 \% \mathrm{O}_{2}$ and $8 \% \mathrm{O}_{2}$, respectively) (Fig. 2c).

\section{The Effect of Oxygen Tension on Bovine Endometrial (ICAR) cell apoptosis}

The effect of oxygen tension on cell apoptosis is presented in Fig. 3. A hypoxic $\left(1 \% \mathrm{O}_{2}\right)$ environment altered cell morphology compared with cells cultured under normal conditions $\left(8 \% \mathrm{O}_{2}\right)$, displaying morphological hallmarks of apoptotic death (Fig. 3A , a and d). Fluorescent images acquired with IncuCyte ${ }^{\mathrm{Ts}}$ (Fig. 3A, b and e) showed greater fluorescence in cells cultured under $1 \%$ $\mathrm{O}_{2}$, indicating a higher activation of caspase-3/7 under hypoxic conditions compared with $8 \% \mathrm{O}_{2}$ (Fig. 3A, b and e). Apoptosis was quantified using the object counting algorithm in which the number of fluorescent objects was indicated with red x's in Fig. 3A (c and f). Quantification analysis showed that hypoxia increased $(\sim 1.6$ fold) the apoptosis ratio (presented as activated caspase 3/7 fluorescent objects count per $\mathrm{mm} 2$ divided by percentage of cell confluence at $48 \mathrm{~h}$ ) compared with cells cultured under normal oxygen tension (Fig. 3B).

\section{The Effect of Oxygen Tension on Exosome Release from Bovine Endometrial Cells (ICAR)}

Exosomes were enriched by buoyant density gradient (see Material and Methods). We fractioned the 100,000 $\times g$ pellet into 12 fractions and the Western blot analysis for TSG101 and CD63 showed positive protein abundance in fractions 1.17 and $1.18 \mathrm{~g} / \mathrm{mL}$ (Fig. 4a). Exosomes were pooled between densities 1.16 and $1.18 \mathrm{~g} / \mathrm{mL}$. Morphology of exosomes was determined by electron microscopy (Fig. 4b), exosomes displayed a cup-shaped morphology with an estimated diameter of $100 \mathrm{~nm}$. Hypoxia did not alter the size distribution of exosomes compared with normal oxygen tension $(123 \pm 2.7 \mathrm{~nm}$ versus $127 \pm 1.7 \mathrm{~nm}$ for $8 \% \mathrm{O}_{2}$ and $1 \% \mathrm{O}_{2}$, respectively) (Fig. 4c). Interestingly,

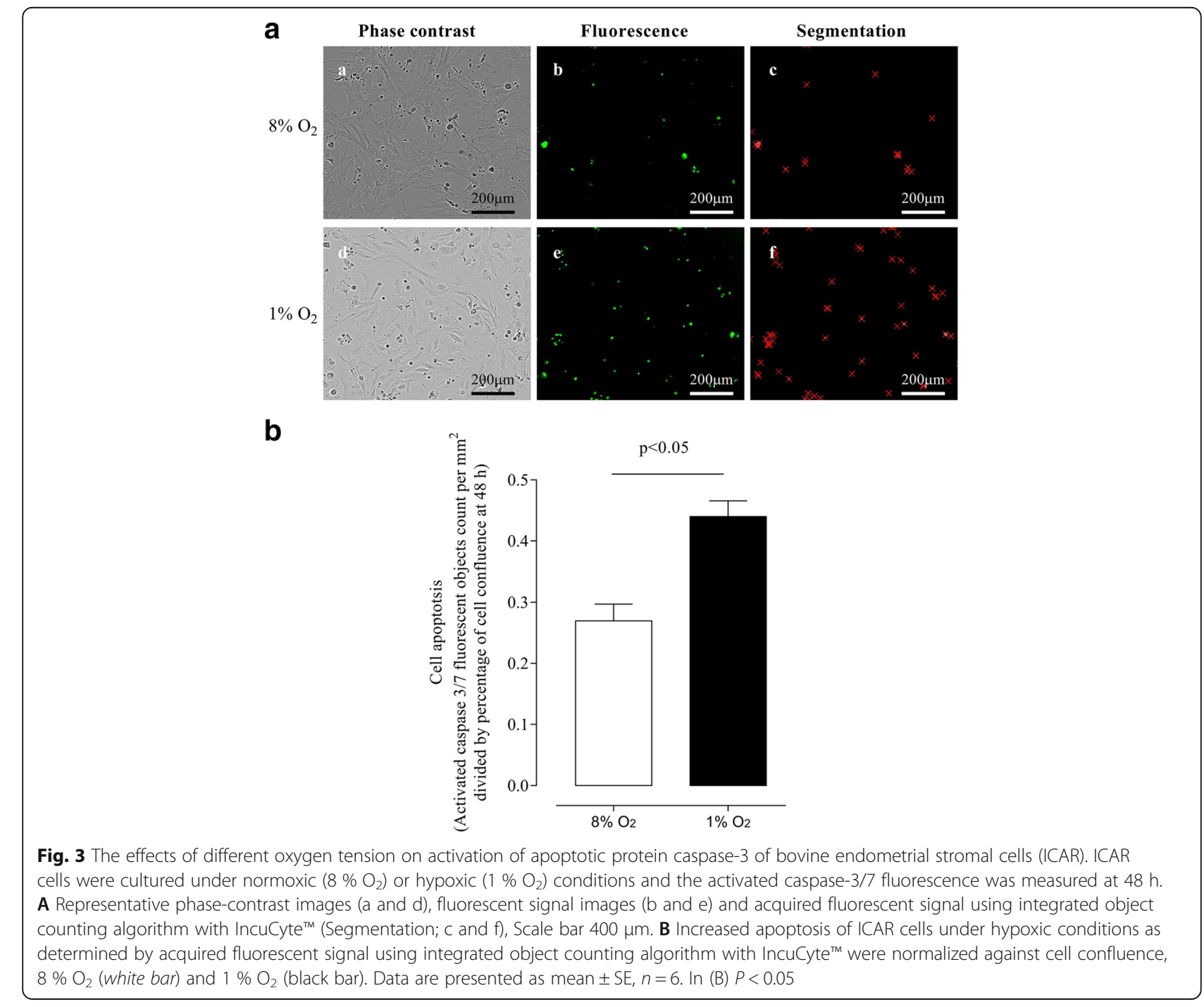



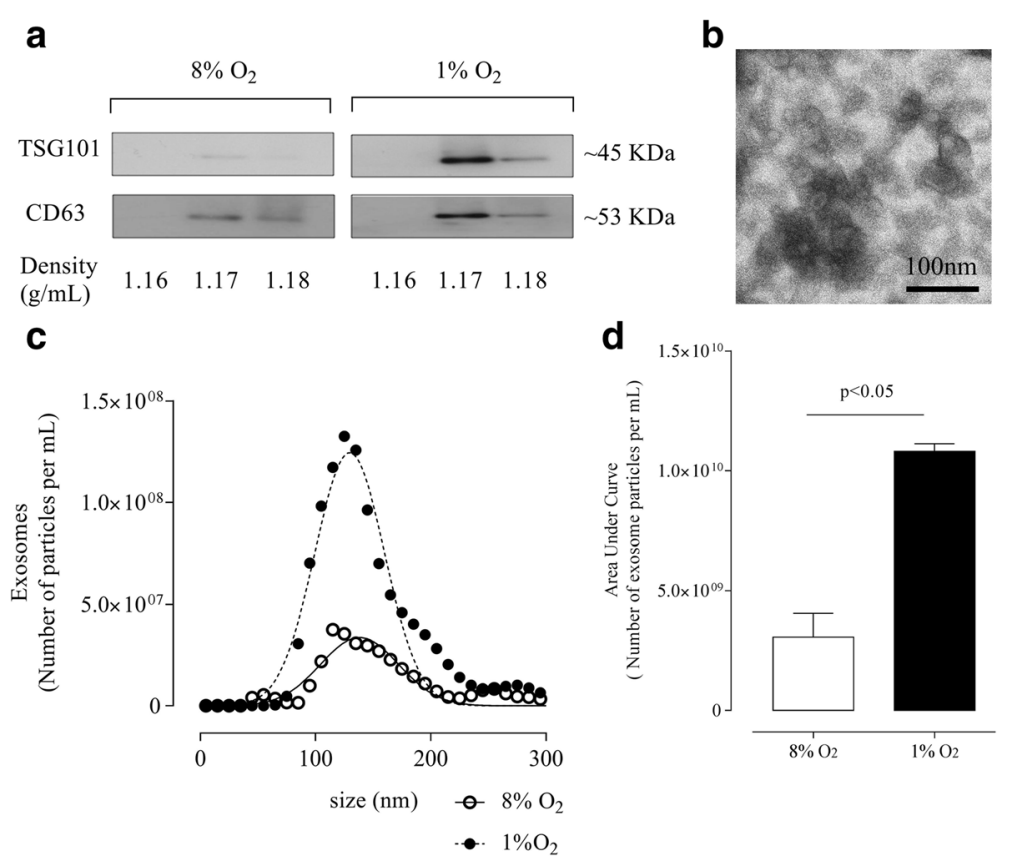

Fig. 4 Characterization of exosomes release from $8 \% \mathrm{O}_{2}$ and $1 \% \mathrm{O}_{2}$ ICAR cell-conditioned media. Exosomes were characterized after enrichment from the 100,000 $\times \mathrm{g}$ pellet by buoyant density centrifugation (see Methods). a Representative Western blot for exosome markers: TSG101 and CD63. b Representative electron micrograph exosome fractions, Scale bar $100 \mathrm{~nm}$. c Representative Nanosight measurement of particle-size distribution exosomes from $8 \% \mathrm{O}_{2}$ and $1 \% \mathrm{O}_{2}$ cell-conditioned media after buoyant density gradient ultracentrifugation. ( $8 \%$ normoxic condition mean size $(127 \pm 1.7 \mathrm{~nm})(0), 1 \%$ hypoxic condition mean size $(123 \pm 2.7 \mathrm{~nm})(\bullet)$ over a period of $48 \mathrm{~h})$. d Exosomes concentration presented as vesicle per million cells per $48 \mathrm{~h}$ was higher $(p<0.05)$ at hypoxia $\left(1 \% \mathrm{O}_{2}\right)$ compared to normal oxygen tension $\left(8 \% \mathrm{O}_{2}\right) ; 8 \% \mathrm{O}_{2}$ (white bar) and $1 \% \mathrm{O}_{2}$ (black bar). Data are presented as mean $\pm \mathrm{SE}, n=3$

hypoxia increased $(\sim 3.6$ fold $)$ the number of exosomes compared with values observed at normal oxygen tension (Fig. 4d).

\section{Proteomic Analysis of Bovine Endometrial ICAR-Derived Exosomes}

Mass spectrometric analysis identified over 250 exosomal proteins with 113 similar proteins identified as present in both exosomes of ICAR cultured at $1 \% \mathrm{O}_{2}$ and at $8 \% \mathrm{O}_{2} 128$ proteins identified as unique to exosomes of ICAR cultured at $1 \% \mathrm{O}_{2} ; 46$ proteins were identified as unique to exosomes of ICAR cultured at $8 \% \mathrm{O}_{2}$ (Table 1 A-C; Fig. 5a). Data were subjected to ontology and pathway analysis using PANTHER and gene ontology algorithms and classified based on biological process (Fig. 5b) and molecular function (Fig. 5c). In biological process, the clusters identified from individual proteins that are unique to and present only in exosomes of ICAR cultured at $1 \% \mathrm{O}_{2}$ but not those at $8 \% \mathrm{O}_{2}$ were: growth $(0.7 \%)$, locomotion $(0.7 \%)$ and reproduction (1.4\%) (Fig. 5b). In molecular functions, the proteins related to binding and catalytic activity were the greatest recognized in both exosomes of ICAR cultured at $1 \% \mathrm{O}_{2}$ and to those of ICAR cultured at $8 \%$ $\mathrm{O}_{2}$ (Fig. 5c).

\section{Discussion}

A successful pregnancy is dependent of having a quality embryo and a receptive uterus synergizing with a synchronized crosstalk between the endometrium and embryo. Any insults or disturbances to its normal course can compromise implantation and the ability for the growing fetus to develop properly in the uterus [26]. The endometrium clearly has important functions in dairy cow pregnancy and we have now shown that exosomal release $(30-120 \mathrm{~nm}$ ) is part of its armamentarium which has analogous properties to similar tissues of other mammalian species.

In the present case, we have shown for the first time the effects of hypoxia on the biological activities of endometrial ICAR cells, including actions on the release and protein content of exosomes. Although it remains to be determined whether exosomes released from ICAR cells at different oxygen tensions also serve different functional goals, our data underscore that the content of exosomes may reflect the physiological state of the cells.

Our non-exosomal characterization of the ICAR cells indicated that the migration and proliferative capacity of ICAR cells decreased, while activation of apoptotic caspase- 3 was enhanced at $1 \% \mathrm{O}_{2}$ (hypoxia), compared with an oxygen tension that was close to the bovine 
Table 1 List of the common proteins identified in exosomes of ICAR cultured at $1 \% \mathrm{O}_{2}$ and at $8 \% \mathrm{O}_{2}$

\begin{tabular}{|c|c|c|c|c|}
\hline \multicolumn{5}{|c|}{ A. List of 113 common proteins identified in exosomes of ICAR cultured at $1 \% \mathrm{O}_{2}$ and at $8 \% \mathrm{O}_{2}$} \\
\hline Protein ID & Name & Gene Name & $\begin{array}{l}\text { Biological Process (Total \# Gene 69; Total } \\
\text { \#Function 146) }\end{array}$ & $\begin{array}{l}\text { Molecular function (Total \# } \\
\text { Gene 69; Total \#Function 81) }\end{array}$ \\
\hline A1L523_BOVIN & Copine II (Fragment) & CPNE2 & & \\
\hline A3KN51_BOVIN & TSG101 protein & TSG101 & Metabolic process & Catalytic activity \\
\hline A5D7L1_BOVIN & CLEC11A protein & CLEC11A & Cellular process/Developmental process & $\begin{array}{l}\text { Binding/Structural molecule } \\
\text { activity }\end{array}$ \\
\hline A5D9D2_BOVIN & $\begin{array}{l}\text { Complement component } 4 \\
\text { binding protein, alpha chain }\end{array}$ & C4BPA & & \\
\hline A5PJ69_BOVIN & SERPINA10 protein & SERPINA10 & Biological regulation/Metabolic process & $\begin{array}{l}\text { Catalytic activity/Enzyme } \\
\text { regulator activity }\end{array}$ \\
\hline A5PJE3_BOVIN & Fibrinogen alpha chain & FGA & & \\
\hline A5PK77_BOVIN & SERPINA11 protein & SERPINA11 & Biological regulation/Metabolic process & $\begin{array}{l}\text { Catalytic activity/Enzyme } \\
\text { regulator activity }\end{array}$ \\
\hline A6QLB7_BOVIN & $\begin{array}{l}\text { Adenylyl cyclase-associated } \\
\text { protein }\end{array}$ & CAP1 & & \\
\hline A6QLL8_BOVIN & $\begin{array}{l}\text { Fructose-bisphosphate } \\
\text { aldolase }\end{array}$ & ALDOA & & \\
\hline A6QNZ7_BOVIN & $\begin{array}{l}\text { Keratin } 10 \text { (Epidermolytic } \\
\text { hyperkeratosis; keratosis } \\
\text { palmaris et plantaris) }\end{array}$ & KRT10 & & \\
\hline A6QPP2_BOVIN & SERPIND1 protein & SERPIND1 & Biological regulation/Metabolic process & $\begin{array}{l}\text { Catalytic activity/Enzyme } \\
\text { regulator activity }\end{array}$ \\
\hline A6QPR1_BOVIN & PCYOX1 protein & PCYOX1 & & \\
\hline LG3BP_BOVIN & Galectin-3-binding protein & LGALS3BP & $\begin{array}{l}\text { Apoptotic process/Biological adhesion/ } \\
\text { Biological regulation/Cellular process/ } \\
\text { Developmental process/Immune system } \\
\text { process/localization/Metabolic process }\end{array}$ & $\begin{array}{l}\text { Catalytic activity/Receptor } \\
\text { activity }\end{array}$ \\
\hline A7MB82_BOVIN & C1QTNF3 protein & C1QTNF3 & & \\
\hline A7YWB6_BOVIN & LOC539596 protein & LOC539596 & & \\
\hline BOJYM4_BOVIN & Tetraspanin & CD63 & & \\
\hline BOJYN6_BOVIN & Alpha-2-HS-glycoprotein & AHSG & & \\
\hline BOJYQO_BOVIN & ALB protein & ALB & & \\
\hline B5B3R8_BOVIN & Alpha S1 casein & CSN1S1 & & \\
\hline E1BDG5_BOVIN & Protein Wnt & WNT5A & $\begin{array}{l}\text { Biological regulation/Cellular process/ } \\
\text { Developmental process/Multicellular } \\
\text { organismal process/Response to stimulus }\end{array}$ & Binding \\
\hline CBG_BOVIN & $\begin{array}{l}\text { Corticosteroid-binding } \\
\text { globulin }\end{array}$ & SERPINA6 & Biological regulation/Metabolic process & $\begin{array}{l}\text { Catalytic activity/Enzyme } \\
\text { regulator activity }\end{array}$ \\
\hline F1MAVO_BOVIN & Fibrinogen beta chain & $\mathrm{FGB}$ & & \\
\hline F1MB08_BOVIN & Alpha-enolase & ENO1 & & \\
\hline F1MC11_BOVIN & Keratin, type I cytoskeletal 14 & KRT14 & & \\
\hline F1MM32_BOVIN & Sulfhydryl oxidase & QSOX1 & & Catalytic activity \\
\hline F1MMK9_BOVIN & Protein AMBP & AMBP & & \\
\hline F1MMP5_BOVIN & $\begin{array}{l}\text { Inter-alpha-trypsin inhibitor } \\
\text { heavy chain } \mathrm{H} 1\end{array}$ & $\mathrm{ITH} 1$ & & \\
\hline ITA3_BOVIN & Integrin alpha-3 & ITGA3 & & \\
\hline F1MNW4_BOVIN & $\begin{array}{l}\text { Inter-alpha-trypsin inhibitor } \\
\text { heavy chain } \mathrm{H} 2\end{array}$ & $\mathrm{ITH} 2$ & & \\
\hline F1MSZ6_BOVIN & Antithrombin-III & SERPINC1 & & \\
\hline
\end{tabular}


Table 1 List of the common proteins identified in exosomes of ICAR cultured at $1 \% \mathrm{O}_{2}$ and at $8 \% \mathrm{O}_{2}$ (Continued)

\begin{tabular}{|c|c|c|c|c|}
\hline F1MTV5_BOVIN & Amino acid transporter & SLC1A5 & & \\
\hline F1MW44_BOVIN & Coagulation factor XIII A chain & F13A1 & & \\
\hline F1MXJ5_BOVIN & IST1 homolog & IST1 & & \\
\hline F1MXX6_BOVIN & Lactadherin & MFGE8 & & \\
\hline F1MY85_BOVIN & $\begin{array}{l}\text { Complement C5a } \\
\text { anaphylatoxin }\end{array}$ & C5 & & \\
\hline F1N045_BOVIN & Complement component C7 & $\mathrm{C} 7$ & & \\
\hline HTRA1_BOVIN & Serine protease HTRA1 & HTRA1 & Cellular process/Metabolic process & Catalytic activity \\
\hline F1N116_BOVIN & Gelsolin & GSN & & \\
\hline F6QVC9_BOVIN & Annexin & ANXA5 & & \\
\hline G3X6N3_BOVIN & Serotransferrin & TF & & \\
\hline G5E5A9_BOVIN & Fibronectin & FN1 & & \\
\hline G5E5V0_BOVIN & $\begin{array}{l}\text { Carboxypeptidase N catalytic } \\
\text { chain }\end{array}$ & CPN1 & & \\
\hline G8JKX6_BOVIN & Tetraspanin (Fragment) & CD9 & & \\
\hline I7CT57_BOVIN & Vitamin D binding protein & & & \\
\hline MOQVZ6_BOVIN & Keratin, type II cytoskeletal 5 & KRT5 & & \\
\hline THRB_BOVIN & Prothrombin & F2 & $\begin{array}{l}\text { Immune system process/Metabolic } \\
\text { process/Response to stimulus }\end{array}$ & Catalytic activity \\
\hline PROC_BOVIN & $\begin{array}{l}\text { Vitamin K-dependent protein } \\
\text { C (Fragment) }\end{array}$ & PROC & Response to stimulus & Binding \\
\hline KNG2_BOVIN & Kininogen-2 & KNG2 & & \\
\hline THYG_BOVIN & Thyroglobulin & TG & Metabolic process & Catalytic activity \\
\hline HBA_BOVIN & Hemoglobin subunit alpha & $\mathrm{HBA}$ & $\begin{array}{l}\text { localization/Multicellular organismal } \\
\text { process }\end{array}$ & \\
\hline HBBF_BOVIN & Hemoglobin fetal subunit beta & & $\begin{array}{l}\text { localization/Multicellular organismal } \\
\text { process }\end{array}$ & \\
\hline ALBU_BOVIN & Serum albumin & ALB & localization & \\
\hline ANXA2_BOVIN & Annexin A2 & ANXA2 & $\begin{array}{l}\text { Developmental process/Metabolic } \\
\text { process }\end{array}$ & \\
\hline ASSY_BOVIN & Argininosuccinate synthase & ASS1 & Cellular process/Metabolic process & Catalytic activity \\
\hline APOH_BOVIN & Beta-2-glycoprotein 1 & $\mathrm{APOH}$ & $\begin{array}{l}\text { Cellular process/Immune system } \\
\text { process/localization/Metabolic process/ } \\
\text { Response to stimulus }\end{array}$ & $\begin{array}{l}\text { Catalytic activity/Receptor } \\
\text { activity/Transporter activity }\end{array}$ \\
\hline CLUS_BOVIN & Clusterin & CLU & & \\
\hline HSP7C_BOVIN & $\begin{array}{l}\text { Heat shock cognate } 71 \mathrm{kDa} \\
\text { protein }\end{array}$ & HSPA8 & $\begin{array}{l}\text { Cellular component organization or } \\
\text { biogenesis/Immune system process/ } \\
\text { Metabolic process/Response to stimulus }\end{array}$ & \\
\hline ANXA7_BOVIN & Annexin A7 & ANXA7 & Metabolic process & \\
\hline ANX11_BOVIN & Annexin A11 & ANXA11 & Metabolic process & \\
\hline A2AP_BOVIN & Alpha-2-antiplasmin & SERPINF2 & Biological regulation/Metabolic process & $\begin{array}{l}\text { Catalytic activity/Enzyme } \\
\text { regulator activity }\end{array}$ \\
\hline A1AT_BOVIN & Alpha-1-antiproteinase & SERPINA1 & Biological regulation/Metabolic process & $\begin{array}{l}\text { Catalytic activity/Enzyme } \\
\text { regulator activity }\end{array}$ \\
\hline GDIB_BOVIN & $\begin{array}{l}\text { Rab GDP dissociation inhibitor } \\
\text { beta }\end{array}$ & GDI2 & $\begin{array}{l}\text { Biological regulation/Cellular process/ } \\
\text { localization/Metabolic process/ } \\
\text { Multicellular organismal process }\end{array}$ & $\begin{array}{l}\text { Binding/Catalytic activity/ } \\
\text { Enzyme regulator activity }\end{array}$ \\
\hline F12AI_BOVIN & Factor Xlla inhibitor & & & \\
\hline ITB1_BOVIN & Integrin beta-1 & ITGB1 & $\begin{array}{l}\text { Biological adhesion/Cellular process/ } \\
\text { Response to stimulus }\end{array}$ & Receptor activity \\
\hline
\end{tabular}


Table 1 List of the common proteins identified in exosomes of ICAR cultured at $1 \% \mathrm{O}_{2}$ and at $8 \% \mathrm{O}_{2}$ (Continued)

\begin{tabular}{|c|c|c|c|c|}
\hline ITIH3_BOVIN & $\begin{array}{l}\text { Inter-alpha-trypsin inhibitor } \\
\text { heavy chain H3 }\end{array}$ & $\mathrm{ITH} 3$ & Biological regulation/Metabolic process & $\begin{array}{l}\text { Binding/Catalytic activity/ } \\
\text { Enzyme regulator activity }\end{array}$ \\
\hline ACTB_BOVIN & Actin, cytoplasmic 1 & ACTB & $\begin{array}{l}\text { Cellular component organization or } \\
\text { biogenesis/Cellular process/ } \\
\text { Developmental process/localization }\end{array}$ & Structural molecule activity \\
\hline ANXA6_BOVIN & Annexin A6 & ANXA6 & Metabolic process & \\
\hline CFAB_BOVIN & Complement factor B & CFB & $\begin{array}{l}\text { Biological adhesion/Cellular process/ } \\
\text { Immune system process/localization/ } \\
\text { Metabolic process/Response to stimulus }\end{array}$ & $\begin{array}{l}\text { Catalytic activity/Receptor } \\
\text { activity/Transporter activity }\end{array}$ \\
\hline TBA1B_BOVIN & Tubulin alpha-1B chain & & $\begin{array}{l}\text { Cellular process/Developmental process/ } \\
\text { localization }\end{array}$ & Structural molecule activity \\
\hline LUM_BOVIN & Lumican & LUM & $\begin{array}{l}\text { Biological adhesion/Biological } \\
\text { regulation/Cellular process/ } \\
\text { Developmental process/Immune system } \\
\text { process/Metabolic process/Multicellular } \\
\text { organismal process }\end{array}$ & Receptor activity \\
\hline UPAR_BOVIN & $\begin{array}{l}\text { Urokinase plasminogen } \\
\text { activator surface receptor }\end{array}$ & PLAUR & & \\
\hline 5NTD_BOVIN & 5'-nucleotidase & NT5E & Metabolic process & Catalytic activity \\
\hline PGM1_BOVIN & Phosphoglucomutase-1 & PGM1 & Cellular process/Metabolic process & Catalytic activity \\
\hline Q09TE3_BOVIN & $\begin{array}{l}\text { Insulin-like growth factor } \\
\text { binding protein acid labile } \\
\text { subunit }\end{array}$ & & & \\
\hline Q17R18_BOVIN & Adenosine kinase & ADK & & \\
\hline FA5_BOVIN & Coagulation factor $\mathrm{V}$ & F5 & $\begin{array}{l}\text { Biological adhesion/Biological } \\
\text { regulation/Cellular process/ } \\
\text { Developmental process/Immune system } \\
\text { process/localization/Metabolic process/ } \\
\text { Multicellular organismal process/ } \\
\text { Response to stimulus }\end{array}$ & $\begin{array}{l}\text { Binding/Catalytic activity/ } \\
\text { Enzyme regulator activity/ } \\
\text { Receptor activity/Transporter } \\
\text { activity }\end{array}$ \\
\hline Q2KIF2_BOVIN & $\begin{array}{l}\text { Leucine-rich alpha-2- } \\
\text { glycoprotein } 1\end{array}$ & LRG1 & $\begin{array}{l}\text { Cellular process/Multicellular organismal } \\
\text { process }\end{array}$ & Receptor activity \\
\hline CBPB2_BOVIN & Carboxypeptidase B2 & CPB2 & Metabolic process & Catalytic activity \\
\hline Q2KJ47_BOVIN & EH-domain containing 2 & EHD2 & $\begin{array}{l}\text { Biological regulation/Cellular process/ } \\
\text { localization/Metabolic process/ } \\
\text { Multicellular organismal process }\end{array}$ & $\begin{array}{l}\text { Binding/Catalytic activity/ } \\
\text { Enzyme regulator activity }\end{array}$ \\
\hline TBB5_BOVIN & Tubulin beta- 5 chain & TUBB5 & $\begin{array}{l}\text { Cellular process/Developmental process/ } \\
\text { localization }\end{array}$ & Structural molecule activity \\
\hline A1BG_BOVIN & Alpha-1B-glycoprotein & $\mathrm{A} 1 \mathrm{BG}$ & $\begin{array}{l}\text { Cellular process/Immune system } \\
\text { process/Response to stimulus }\end{array}$ & Binding/Receptor activity \\
\hline HPT_BOVIN & Haptoglobin & HP & $\begin{array}{l}\text { Biological regulation/Immune system } \\
\text { process/localization/Metabolic process/ } \\
\text { Multicellular organismal process/ } \\
\text { Reproduction/Response to stimulus }\end{array}$ & $\begin{array}{l}\text { Binding/Catalytic activity/ } \\
\text { Enzyme regulator activity/ } \\
\text { Receptor activity }\end{array}$ \\
\hline CO3_BOVIN & Complement C3 & C3 & $\begin{array}{l}\text { Biological regulation/Cellular process/ } \\
\text { Metabolic process/Response to stimulus }\end{array}$ & $\begin{array}{l}\text { Binding/Catalytic activity/ } \\
\text { Enzyme regulator activity }\end{array}$ \\
\hline Q3MHH8_BOVIN & Alpha-amylase & AMY2A & & \\
\hline SAHH_BOVIN & Adenosylhomocysteinase & $\mathrm{AHCY}$ & Cellular process/Metabolic process & Catalytic activity \\
\hline CO9_BOVIN & Complement component C9 & C9 & $\begin{array}{l}\text { Cellular process/localization/Metabolic } \\
\text { process/Response to stimulus }\end{array}$ & $\begin{array}{l}\text { Catalytic activity/Receptor } \\
\text { activity/Transporter activity }\end{array}$ \\
\hline Q3MHW2_BOVIN & F10 protein (Fragment) & F10 & & \\
\hline Q3MHZO_BOVIN & FLOT1 protein (Fragment) & FLOT1 & & \\
\hline Q3SYRO_BOVIN & $\begin{array}{l}\text { Serpin peptidase inhibitor, clade } \\
\text { A (Alpha-1 antiproteinase, } \\
\text { antitrypsin), member } 7\end{array}$ & SERPINA7 & & \\
\hline
\end{tabular}


Table 1 List of the common proteins identified in exosomes of ICAR cultured at $1 \% \mathrm{O}_{2}$ and at $8 \% \mathrm{O}_{2}$ (Continued)

\begin{tabular}{|c|c|c|c|c|}
\hline FETA_BOVIN & Alpha-fetoprotein & AFP & \multirow[t]{2}{*}{ Developmental process/localization } & \\
\hline Q3SZH5_BOVIN & Angiotensinogen & AGT & & \\
\hline HEMO_BOVIN & Hemopexin & $\mathrm{HPX}$ & \multirow[t]{2}{*}{ localization } & \\
\hline Q3SZZ9_BOVIN & FGG protein & FGG & & \\
\hline PGK1_BOVIN & Phosphoglycerate kinase 1 & PGK1 & \multirow[t]{2}{*}{ Metabolic process } & \multirow[t]{2}{*}{ Catalytic activity } \\
\hline Q3T101_BOVIN & IGL@ protein & IGL@ & & \\
\hline G6PI_BOVIN & $\begin{array}{l}\text { Glucose-6-phosphate } \\
\text { isomerase }\end{array}$ & GPI & \multirow[t]{3}{*}{ Metabolic process } & \multirow[t]{3}{*}{ Catalytic activity } \\
\hline Q3ZBX0_BOVIN & Basigin & BSG & & \\
\hline Q3ZC87_BOVIN & Pyruvate kinase (Fragment) & PKM2 & & \\
\hline Q3ZCI4_BOVIN & $\begin{array}{l}\text { 6-phosphogluconate } \\
\text { dehydrogenase, } \\
\text { decarboxylating }\end{array}$ & PGD & \multirow[t]{2}{*}{ Metabolic process } & \multirow[t]{2}{*}{ Catalytic activity } \\
\hline FETUB_BOVIN & Fetuin-B & FETUB & & \\
\hline EHD1_BOVIN & EH domain-containing protein 1 & EHD1 & $\begin{array}{l}\text { Biological regulation/Cellular process/ } \\
\text { localization/Metabolic process/ } \\
\text { Multicellular organismal process }\end{array}$ & $\begin{array}{l}\text { Binding/Catalytic activity/ } \\
\text { Enzyme regulator activity }\end{array}$ \\
\hline HPPD_BOVIN & $\begin{array}{l}\text { 4-hydroxyphenylpyruvate } \\
\text { dioxygenase }\end{array}$ & HPD & \multirow[t]{3}{*}{ Metabolic process } & \multirow[t]{3}{*}{ Catalytic activity } \\
\hline Q5EA67_BOVIN & $\begin{array}{l}\text { Inter-alpha (Globulin) inhibitor } \\
\text { H4 (Plasma Kallikrein-sensitive } \\
\text { glycoprotein) }\end{array}$ & $\mathrm{ITH} 4$ & & \\
\hline Q5GN72_BOVIN & Alpha-1-acid glycoprotein & agp & & \\
\hline BHMT1_BOVIN & $\begin{array}{l}\text { Betaine-homocysteine S- } \\
\text { methyltransferase } 1\end{array}$ & BHMT & \multirow[t]{3}{*}{ Cellular process/Metabolic process } & \multirow[t]{3}{*}{ Catalytic activity } \\
\hline Q5J801_BOVIN & Endopin 2B & & & \\
\hline Q6T182_BOVIN & $\begin{array}{l}\text { Sex hormone-binding globulin } \\
\text { (Fragment) }\end{array}$ & SHBG & & \\
\hline A2MG_BOVIN & Alpha-2-macroglobulin & $\mathrm{A} 2 \mathrm{M}$ & $\begin{array}{l}\text { Biological regulation/Cellular process/ } \\
\text { Immune system process/Metabolic } \\
\text { process/Response to stimulus }\end{array}$ & $\begin{array}{l}\text { Binding/Catalytic activity/ } \\
\text { Enzyme regulator activity }\end{array}$ \\
\hline PEDF_BOVIN & $\begin{array}{l}\text { Pigment epithelium-derived } \\
\text { factor }\end{array}$ & SERPINF1 & Biological regulation/Metabolic process & $\begin{array}{l}\text { Catalytic activity/Enzyme } \\
\text { regulator activity }\end{array}$ \\
\hline CHIA_BOVIN & Acidic mammalian chitinase & $\mathrm{CHIA}$ & $\begin{array}{l}\text { Immune system process/Metabolic } \\
\text { process/Response to stimulus }\end{array}$ & Binding/Catalytic activity \\
\hline IPSP_BOVIN & $\begin{array}{l}\text { Plasma serine protease } \\
\text { inhibitor }\end{array}$ & SERPINA5 & Biological regulation/Metabolic process & $\begin{array}{l}\text { Catalytic activity/Enzyme } \\
\text { regulator activity }\end{array}$ \\
\hline SPA31_BOVIN & Serpin A3-1 & SERPINA3-1 & Biological regulation/Metabolic process & $\begin{array}{l}\text { Catalytic activity/Enzyme } \\
\text { regulator activity }\end{array}$ \\
\hline V6F9A2_BOVIN & $\begin{array}{l}\text { Apolipoprotein A-I } \\
\text { preproprotein }\end{array}$ & APOA1 & & \\
\hline \multicolumn{5}{|c|}{ B. List of 128 unique proteins identified in exosomes of ICAR cultured at $1 \% \mathrm{O}_{2}$} \\
\hline Protein ID & Name & Gene Name & $\begin{array}{l}\text { Biological Process (Total \# Gene 22; Total } \\
\text { \#Function 49) }\end{array}$ & $\begin{array}{l}\text { Molecular function (Total \# } \\
\text { Gene 22; Total \#Function 28) }\end{array}$ \\
\hline G3X6T9_BOVIN & Flotillin-2 (Fragment) & FLOT2 & & \\
\hline TSP1_BOVIN & Thrombospondin-1 & THBS1 & & \\
\hline F1N2L9_BOVIN & $\begin{array}{l}\text { 4-trimethylaminobutyraldehyde } \\
\text { dehydrogenase }\end{array}$ & ALDH9A1 & & \\
\hline E1B9F6_BOVIN & Elongation factor 1-alpha & EEF1A1 & & \\
\hline
\end{tabular}


Table 1 List of the common proteins identified in exosomes of ICAR cultured at $1 \% \mathrm{O}_{2}$ and at $8 \% \mathrm{O}_{2}$ (Continued)

\begin{tabular}{|c|c|c|c|c|}
\hline APOE_BOVIN & Apolipoprotein E & APOE & $\begin{array}{l}\text { Apoptotic process/Biological regulation/ } \\
\text { Cellular component organization or } \\
\text { biogenesis/Cellular process/ } \\
\text { Developmental process/Growth/ } \\
\text { localization/Metabolic process/ } \\
\text { Multicellular organismal process/ } \\
\text { Response to stimulus }\end{array}$ & $\begin{array}{l}\text { Binding/Catalytic activity/ } \\
\text { Enzyme regulator activity/ } \\
\text { Transporter activity }\end{array}$ \\
\hline G1K1R6_BOVIN & Galactokinase & GALK1 & & \\
\hline G3P_BOVIN & $\begin{array}{l}\text { Glyceraldehyde-3-phosphate } \\
\text { dehydrogenase }\end{array}$ & GAPDH & Metabolic process & Catalytic activity \\
\hline Q0P5B0_BOVIN & Arrestin domain containing 1 & ARRDC1 & & \\
\hline RL40_BOVIN & $\begin{array}{l}\text { Ubiquitin-60S ribosomal } \\
\text { protein } L 40\end{array}$ & UBA52 & Metabolic process & $\begin{array}{l}\text { Binding/Structural molecule } \\
\text { activity }\end{array}$ \\
\hline A5D9B6_BOVIN & Syntenin & SDCBP & & \\
\hline Q8HZY1_BOVIN & $\begin{array}{l}\text { Serine protease inhibitor clade } \\
\text { E member } 2\end{array}$ & SERPINE2 & & \\
\hline Q5E962_BOVIN & $\begin{array}{l}\text { Aldo-keto reductase family } 1 \text {, } \\
\text { member } \mathrm{B} 1\end{array}$ & AKR1B1 & & \\
\hline A7MBH9_BOVIN & GNAI2 protein & GNAI2 & $\begin{array}{l}\text { Biological regulation/Cellular process/ } \\
\text { Metabolic process/Response to stimulus }\end{array}$ & Binding/Catalytic activity \\
\hline GBB2_BOVIN & $\begin{array}{l}\text { Guanine nucleotide-binding } \\
\text { protein } G(I) / G(S) / G(T) \text { subunit } \\
\text { beta-2 }\end{array}$ & GNB2 & $\begin{array}{l}\text { Cellular process/Metabolic process/ } \\
\text { Multicellular organismal process }\end{array}$ & Binding/Catalytic activity \\
\hline I6YIV1_BOVIN & Annexin & & & \\
\hline F16P1_BOVIN & Fructose-1,6-bisphosphatase 1 & FBP1 & Metabolic process & \\
\hline F1N3Q7_BOVIN & Apolipoprotein A-IV & APOA4 & & \\
\hline AK1A1_BOVIN & $\begin{array}{l}\text { Alcohol dehydrogenase } \\
{[\mathrm{NADP}(+)]}\end{array}$ & AKR1A1 & localization/Metabolic process & $\begin{array}{l}\text { Catalytic activity/Transporter } \\
\text { activity }\end{array}$ \\
\hline A5D784_BOVIN & CPNE8 protein & CPNE8 & localization & \\
\hline HS90A_BOVIN & $\begin{array}{l}\text { Heat shock protein HSP 90- } \\
\text { alpha }\end{array}$ & HSP90AA1 & $\begin{array}{l}\text { Immune system process/ } \\
\text { Metabolic process/Response to stimulus }\end{array}$ & \\
\hline Q1JPA2_BOVIN & $\begin{array}{l}\text { Eukaryotic translation } \\
\text { elongation factor } 1 \text { gamma } \\
\text { (Fragment) }\end{array}$ & EEF1G & & \\
\hline SERA_BOVIN & $\begin{array}{l}\text { D-3-phosphoglycerate } \\
\text { dehydrogenase }\end{array}$ & PHGDH & Metabolic process & Catalytic activity \\
\hline Q3T085_BOVIN & OGN protein & OGN & & \\
\hline A8DBT6_BOVIN & $\begin{array}{l}\text { Monocyte differentiation } \\
\text { antigen CD14 }\end{array}$ & CD14 & & \\
\hline A5PK73_BOVIN & $\begin{array}{l}\text { Fructose-bisphosphate } \\
\text { aldolase }\end{array}$ & ALDOB & & \\
\hline G5E5U7_BOVIN & $\begin{array}{l}\text { S-adenosylmethionine } \\
\text { synthase }\end{array}$ & MAT1A & & \\
\hline F1N2W0_BOVIN & Prostaglandin reductase 1 & PTGR1 & & \\
\hline IF4A1_BOVIN & Eukaryotic initiation factor $4 \mathrm{~A}-\mathrm{I}$ & EIF4A1 & Biological regulation/Metabolic process & $\begin{array}{l}\text { Binding/Catalytic activity/ } \\
\text { Translation regulator activity }\end{array}$ \\
\hline Q05B55_BOVIN & IGK protein & IGK & & \\
\hline F1N1D4_BOVIN & Protein tweety homolog & TTYH3 & localization & Transporter activity \\
\hline A4FV94_BOVIN & KRT6A protein & KRT6A & & \\
\hline RGN_BOVIN & Regucalcin & RGN & $\begin{array}{l}\text { Cellular process/localization/Metabolic } \\
\text { process }\end{array}$ & Binding/Catalytic activity \\
\hline 1433E_BOVIN & 14-3-3 protein epsilon & YWHAE & Cellular process & \\
\hline
\end{tabular}


Table 1 List of the common proteins identified in exosomes of ICAR cultured at $1 \% \mathrm{O}_{2}$ and at $8 \% \mathrm{O}_{2}$ (Continued)

\begin{tabular}{|c|c|c|c|c|}
\hline Q2HJB6_BOVIN & $\begin{array}{l}\text { Procollagen C-endopeptidase } \\
\text { enhancer }\end{array}$ & PCOLCE & $\begin{array}{l}\text { Biological adhesion/Biological } \\
\text { regulation/Cellular process/ } \\
\text { Developmental process/Immune system } \\
\text { process/localization/Metabolic process/ } \\
\text { Multicellular organismal process/ } \\
\text { Response to stimulus }\end{array}$ & $\begin{array}{l}\text { Binding/Catalytic activity/ } \\
\text { Enzyme regulator activity/ } \\
\text { Receptor activity/Transporter } \\
\text { activity }\end{array}$ \\
\hline B8YB76_BOVIN & $\begin{array}{l}\text { Homogentisate 1,2- } \\
\text { dioxygenase }\end{array}$ & HGD & & \\
\hline DHSO_BOVIN & Sorbitol dehydrogenase & SORD & Metabolic process & Catalytic activity \\
\hline HS71A_BOVIN & Heat shock $70 \mathrm{kDa}$ protein $1 \mathrm{~A}$ & HSPA1A & $\begin{array}{l}\text { Cellular component organization or } \\
\text { biogenesis/Immune system process/ } \\
\text { Metabolic process/Response to stimulus }\end{array}$ & \\
\hline Q3ZBQ9_BOVIN & APOM protein & APOM & & \\
\hline PYGL_BOVIN & $\begin{array}{l}\text { Glycogen phosphorylase, liver } \\
\text { form }\end{array}$ & PYGL & Metabolic process & Catalytic activity \\
\hline A6QP30_BOVIN & CPN2 protein & CPN2 & $\begin{array}{l}\text { Cellular process/Multicellular organismal } \\
\text { process }\end{array}$ & Receptor activity \\
\hline ARF3_BOVIN & ADP-ribosylation factor 3 & ARF3 & $\begin{array}{l}\text { Cellular process/localization/Metabolic } \\
\text { process }\end{array}$ & Binding/Catalytic activity \\
\hline G3MYH4_BOVIN & Tetraspanin (Fragment) & CD81 & & \\
\hline ACTC_BOVIN & Actin, alpha cardiac muscle 1 & ACTC1 & $\begin{array}{l}\text { Cellular component organization or } \\
\text { biogenesis/Cellular process/ } \\
\text { Developmental process/localization }\end{array}$ & Structural molecule activity \\
\hline GALM_BOVIN & Aldose 1-epimerase & GALM & Metabolic process & Catalytic activity \\
\hline TSN6_BOVIN & Tetraspanin-6 & TSPAN6 & $\begin{array}{l}\text { Biological adhesion/Cellular process/ } \\
\text { Immune system process/Multicellular } \\
\text { organismal process/Reproduction/ } \\
\text { Response to stimulus }\end{array}$ & Binding/Receptor activity \\
\hline Q3ZC83_BOVIN & $\begin{array}{l}\text { Solute carrier family } 29 \\
\text { (Nucleoside transporters), } \\
\text { member } 1\end{array}$ & SLC29A1 & localization/Metabolic process & Transporter activity \\
\hline B4GA1_BOVIN & Beta-1,4-glucuronyltransferase 1 & B4GAT1 & Metabolic process & Catalytic activity \\
\hline ADA10_BOVIN & $\begin{array}{l}\text { Disintegrin and } \\
\text { metalloproteinase domain- } \\
\text { containing protein } 10\end{array}$ & ADAM10 & $\begin{array}{l}\text { Apoptotic process/Developmental } \\
\text { process/Reproduction }\end{array}$ & \\
\hline A6QR28_BOVIN & $\begin{array}{l}\text { Phosphoserine } \\
\text { aminotransferase }\end{array}$ & PSAT1 & Metabolic process & Catalytic activity \\
\hline Q1JPB6_BOVIN & $\begin{array}{l}\text { Acetyl-Coenzyme A } \\
\text { acetyltransferase } 2\end{array}$ & ACAT2 & & \\
\hline DDBX_BOVIN & Dihydrodiol dehydrogenase 3 & & localization/Metabolic process & $\begin{array}{l}\text { Catalytic activity/Transporter } \\
\text { activity }\end{array}$ \\
\hline A2VE11_BOVIN & IGSF8 protein & IGSF8 & & \\
\hline F1MS32_BOVIN & Apolipoprotein D & APOD & & \\
\hline A6QP64_BOVIN & VPS37B protein (Fragment) & VPS37B & & \\
\hline Q2KIW4_BOVIN & $\begin{array}{l}\text { Lecithin-cholesterol } \\
\text { acyltransferase }\end{array}$ & LCAT & Metabolic process & Catalytic activity \\
\hline GBB1_BOVIN & $\begin{array}{l}\text { Guanine nucleotide-binding } \\
\text { protein } G(I) / G(S) / G(T) \text { subunit } \\
\text { beta-1 }\end{array}$ & GNB1 & Cellular process/Metabolic process & Binding/Catalytic activity \\
\hline GNA11_BOVIN & $\begin{array}{l}\text { Guanine nucleotide-binding } \\
\text { protein subunit alpha-11 }\end{array}$ & GNA11 & $\begin{array}{l}\text { Biological regulation/Cellular process/ } \\
\text { Metabolic process/Response to stimulus }\end{array}$ & Catalytic activity \\
\hline Q17QK4_BOVIN & $\begin{array}{l}\text { Epoxide hydrolase 2, } \\
\text { cytoplasmic }\end{array}$ & $\mathrm{EPHX} 2$ & & \\
\hline
\end{tabular}


Table 1 List of the common proteins identified in exosomes of ICAR cultured at $1 \% \mathrm{O}_{2}$ and at $8 \% \mathrm{O}_{2}$ (Continued)

\begin{tabular}{|c|c|c|c|c|}
\hline K2C7_BOVIN & Keratin, type II cytoskeletal 7 & KRT7 & $\begin{array}{l}\text { Cellular component organization or } \\
\text { biogenesis/Cellular process/ } \\
\text { Developmental process }\end{array}$ & Structural molecule activity \\
\hline CLIC1_BOVIN & $\begin{array}{l}\text { Chloride intracellular channel } \\
\text { protein } 1\end{array}$ & CLIC1 & $\begin{array}{l}\text { Biological regulation/Cellular process/ } \\
\text { Metabolic process/Response to stimulus }\end{array}$ & $\begin{array}{l}\text { Binding/Catalytic activity/ } \\
\text { Structural molecule activity/ } \\
\text { Translation regulator activity }\end{array}$ \\
\hline Q08DW4_BOVIN & $\begin{array}{l}\text { Mannan-binding lectin serine } \\
\text { peptidase } 1 \text { (C4/C2 activating } \\
\text { component of Ra-reactive factor) }\end{array}$ & MASP1 & & \\
\hline B4GT1_BOVIN & Beta-1,4-galactosyltransferase 1 & B4GALT1 & & \\
\hline A5D7E6_BOVIN & Tetraspanin & CD82 & Cellular process/Response to stimulus & Binding/Receptor activity \\
\hline A5D973_BOVIN & $\begin{array}{l}\text { Alpha isoform of regulatory } \\
\text { subunit } A \text {, protein } \\
\text { phosphatase } 2\end{array}$ & PPP2R1A & & \\
\hline E1B726_BOVIN & Plasminogen & PLG & & \\
\hline G5E619_BOVIN & Histone $\mathrm{H} 2 \mathrm{~B}$ & LOC101904777 & $\begin{array}{l}\text { Cellular component organization or } \\
\text { biogenesis/Cellular process/Metabolic } \\
\text { process }\end{array}$ & Binding \\
\hline ADIPO_BOVIN & Adiponectin & ADIPOQ & & \\
\hline F1MBC5_BOVIN & Coagulation factor IX & F9 & & \\
\hline A2VDL2_BOVIN & $\begin{array}{l}\text { Solute carrier family } 2 \\
\text { (Facilitated glucose } \\
\text { transporter), member } 3\end{array}$ & SLC2A3 & & \\
\hline VPS4B_BOVIN & $\begin{array}{l}\text { Vacuolar protein sorting- } \\
\text { associated protein } 4 B\end{array}$ & VPS4B & & \\
\hline G3X8B1_BOVIN & $\begin{array}{l}\text { Peptidyl-prolyl cis-trans } \\
\text { isomerase }\end{array}$ & LOC613401 & & \\
\hline K4JB97_BOVIN & Alpha-2-macroglobulin variant 4 & $\mathrm{~A} 2 \mathrm{M}$ & & \\
\hline ACTG_BOVIN & Actin, cytoplasmic 2 & ACTG1 & $\begin{array}{l}\text { Cellular component organization or } \\
\text { biogenesis/Cellular process/localization }\end{array}$ & Structural molecule activity \\
\hline Q1JPG7_BOVIN & Pyruvate kinase & PKLR & & \\
\hline GTR1_BOVIN & $\begin{array}{l}\text { Solute carrier family } 2 \text {, } \\
\text { facilitated glucose transporter } \\
\text { member } 1\end{array}$ & SLC2A1 & & \\
\hline F1N342_BOVIN & Protein tweety homolog & TYH 2 & localization & Transporter activity \\
\hline ADHX_BOVIN & Alcohol dehydrogenase class-3 & ADH5 & Metabolic process & Catalytic activity \\
\hline URP2_BOVIN & Fermitin family homolog 3 & FERMT3 & & \\
\hline E1B7N2_BOVIN & Histone $\mathrm{H} 4$ & HIST1H4I & $\begin{array}{l}\text { Cellular component organization or } \\
\text { biogenesis/Cellular process/Metabolic } \\
\text { process }\end{array}$ & Binding \\
\hline EF2_BOVIN & Elongation factor 2 & EEF2 & Biological regulation/Metabolic process & $\begin{array}{l}\text { Binding/Translation regulator } \\
\text { activity }\end{array}$ \\
\hline KLKB1_BOVIN & Plasma kallikrein & KLKB1 & $\begin{array}{l}\text { Biological regulation/localization/ } \\
\text { Metabolic process/Response to stimulus }\end{array}$ & $\begin{array}{l}\text { Binding/Catalytic activity/ } \\
\text { Enzyme regulator activity/ } \\
\text { Receptor activity }\end{array}$ \\
\hline ESTD_BOVIN & S-formylglutathione hydrolase & ESD & Metabolic process & Catalytic activity \\
\hline SEPR_BOVIN & Prolyl endopeptidase FAP & FAP & $\begin{array}{l}\text { Cellular process/Immune system } \\
\text { process/localization/Metabolic process/ } \\
\text { Multicellular organismal process / } \\
\text { Response to stimulus }\end{array}$ & Binding/Catalytic activity \\
\hline Q5EA54_BOVIN & $\begin{array}{l}\text { Solute carrier family } 3 \\
\text { (Activators of dibasic and } \\
\text { neutral amino acid transport), } \\
\text { member } 2\end{array}$ & SLC3A2 & & \\
\hline
\end{tabular}


Table 1 List of the common proteins identified in exosomes of ICAR cultured at $1 \% \mathrm{O}_{2}$ and at $8 \% \mathrm{O}_{2}$ (Continued)

\begin{tabular}{|c|c|c|c|c|}
\hline Q1JPD9_BOVIN & $\begin{array}{l}\text { G protein-coupled receptor, } \\
\text { family } C \text {, group } 5 \text {, member B }\end{array}$ & GPRC5B & Cellular process & Receptor activity \\
\hline F1MS05_BOVIN & Aconitate hydratase & ACO1 & & \\
\hline F1MJ12_BOVIN & $\begin{array}{l}\text { Complement C1s } \\
\text { subcomponent }\end{array}$ & C1S & & \\
\hline CNDP2_BOVIN & $\begin{array}{l}\text { Cytosolic non-specific } \\
\text { dipeptidase }\end{array}$ & CNDP2 & Metabolic process & Catalytic activity \\
\hline Q2TBQ1_BOVIN & $\begin{array}{l}\text { Coagulation factor XIII, B } \\
\text { polypeptide }\end{array}$ & $\mathrm{F} 13 \mathrm{~B}$ & $\begin{array}{l}\text { Biological adhesion/Cellular process/ } \\
\text { Immune system process/localization/ } \\
\text { Metabolic process/Response to stimulus }\end{array}$ & $\begin{array}{l}\text { Catalytic activity/Receptor } \\
\text { activity/Transporter activity }\end{array}$ \\
\hline Q1JP72_BOVIN & $\begin{array}{l}\text { Colony stimulating factor } 1 \\
\text { receptor }\end{array}$ & CSF1R & & \\
\hline QOVD03_BOVIN & CD44 antigen & CD44 & & \\
\hline G3X6Y4_BOVIN & Osteomodulin & $\mathrm{OMD}$ & & \\
\hline GAMT_BOVIN & $\begin{array}{l}\text { Guanidinoacetate N- } \\
\text { methyltransferase }\end{array}$ & GAMT & & \\
\hline WWA1_BOVIN & $\begin{array}{l}\text { von Willebrand factor A } \\
\text { domain-containing protein } 1\end{array}$ & WWA1 & & \\
\hline SERC3_BOVIN & Serine incorporator 3 & SERINC3 & & \\
\hline Q862H8_BOVIN & $\begin{array}{l}\text { Similar to } 40 \text { S ribosomal } \\
\text { protein SA (P40) (Fragment) }\end{array}$ & & & \\
\hline A8E4P3_BOVIN & STOM protein & STOM & & \\
\hline F1MHP6_BOVIN & Adenylosuccinate lyase & ADSL & & \\
\hline E1BMG9_BOVIN & $\begin{array}{l}\text { 10-formyltetrahydrofolate } \\
\text { dehydrogenase }\end{array}$ & ALDH1L1 & Metabolic process & Catalytic activity \\
\hline Q705V4_BOVIN & Kappa-casein (Fragment) & $\operatorname{csn} 3$ & & \\
\hline G3X6Q8_BOVIN & Pentraxin-related protein PTX3 & PTX3 & & \\
\hline K7QEL2_BOVIN & MHC class I antigen & BoLA & & \\
\hline TCPQ_BOVIN & $\begin{array}{l}\text { T-complex protein } 1 \text { subunit } \\
\text { theta }\end{array}$ & ССТ8 & $\begin{array}{l}\text { Cellular component organization or } \\
\text { biogenesis / Metabolic process }\end{array}$ & \\
\hline F1N6ZO_BOVIN & $\begin{array}{l}265 \text { proteasome non-ATPase } \\
\text { regulatory subunit } 5\end{array}$ & PSMD5 & & \\
\hline ARLY_BOVIN & Argininosuccinate lyase & ASL & Metabolic process & Catalytic activity \\
\hline E1BNG2_BOVIN & alpha-1,2-Mannosidase & MAN1A1 & Metabolic process & \\
\hline F1MU79_BOVIN & $\begin{array}{l}\text { Peptidyl-prolyl cis-trans isomer- } \\
\text { ase FKBP4 }\end{array}$ & FKBP4 & & \\
\hline DPYL2_BOVIN & $\begin{array}{l}\text { Dihydropyrimidinase-related } \\
\text { protein } 2\end{array}$ & DPYSL2 & Metabolic process & Catalytic activity \\
\hline PRS23_BOVIN & Serine protease 23 & PRSS23 & & \\
\hline BOJYN1_BOVIN & Cathepsin L2 & CTSL2 & & \\
\hline A4FV99_BOVIN & FCNB protein & FCNB & & \\
\hline A7YW37_BOVIN & CD58 protein (Fragment) & CD58 & $\begin{array}{l}\text { Immune system process/ } \\
\text { Response to stimulus }\end{array}$ & Binding \\
\hline F1MTP5_BOVIN & WD repeat-containing protein 1 & WDR1 & & \\
\hline A7E3D0_BOVIN & CCDC45 protein (Fragment) & CCDC45 & & \\
\hline QOVCK1_BOVIN & $\begin{array}{l}\text { Myeloid-associated } \\
\text { differentiation marker }\end{array}$ & MYADM & & \\
\hline A1L570_BOVIN & Ephrin-B1 & EFNB1 & $\begin{array}{l}\text { Biological regulation/Cellular component } \\
\text { organization or biogenesis/Cellular } \\
\text { process/Developmental process/ } \\
\text { locomotion/Multicellular organismal } \\
\text { process/Response to stimulus }\end{array}$ & Binding \\
\hline
\end{tabular}


Table 1 List of the common proteins identified in exosomes of ICAR cultured at $1 \% \mathrm{O}_{2}$ and at $8 \% \mathrm{O}_{2}$ (Continued)

\begin{tabular}{|c|c|c|c|c|}
\hline F1N049_BOVIN & $\begin{array}{l}\text { Actin-related protein } 3 \\
\text { (Fragment) }\end{array}$ & ACTR3 & & \\
\hline PAl1_BOVIN & Plasminogen activator inhibitor 1 & SERPINE1 & Biological regulation/Metabolic process & $\begin{array}{l}\text { Catalytic activity/Enzyme } \\
\text { regulator activity }\end{array}$ \\
\hline Q3ZC30_BOVIN & Sulfotransferase & SULT1E1 & & \\
\hline COL11_BOVIN & Collectin-11 & COLEC11 & $\begin{array}{l}\text { Biological regulation/Immune system } \\
\text { process/Multicellular organismal process }\end{array}$ & \\
\hline MPZL1_BOVIN & $\begin{array}{l}\text { Myelin protein zero-like } \\
\text { protein } 1\end{array}$ & MPZL1 & Cellular process/localization & Transporter activity \\
\hline G5E595_BOVIN & $\begin{array}{l}\text { Lys-63-specific deubiquitinase } \\
\text { BRCC36 }\end{array}$ & BRCC3 & & \\
\hline O18977_BOVIN & Tenascin-X & TN-X & & \\
\hline A6H7D3_BOVIN & KRT18 protein (Fragment) & KRT18 & & \\
\hline J9ZXG5_BOVIN & Integrin alpha $\vee$ subunit & & & \\
\hline BOJYN3_BOVIN & L-lactate dehydrogenase & LDHB & & \\
\hline MB211_BOVIN & Protein mab-21-like 1 & MAB21L1 & & \\
\hline E1B7R4_BOVIN & $\begin{array}{l}\text { Eukaryotic translation initiation } \\
\text { factor } 3 \text { subunit A }\end{array}$ & EIF3A & Biological regulation/Metabolic process & $\begin{array}{l}\text { Binding/Translation regulator } \\
\text { activity }\end{array}$ \\
\hline \multicolumn{5}{|c|}{ C. List of 46 unique proteins identified in exosomes of ICAR cultured at $8 \% \mathrm{O}_{2}$} \\
\hline Protein ID & Name & Gene Name & $\begin{array}{l}\text { Biological Process (Total \# Gene 22; Total } \\
\text { \#Function 49) }\end{array}$ & $\begin{array}{l}\text { Molecular function (Total \# } \\
\text { Gene 22; Total \#Function 28) }\end{array}$ \\
\hline F1MMD7_BOVIN & $\begin{array}{l}\text { Inter-alpha-trypsin inhibitor } \\
\text { heavy chain } \mathrm{H} 4\end{array}$ & $\mathrm{ITIH} 4$ & & \\
\hline F1N3A1_BOVIN & Thrombospondin-1 & THBS1 & & \\
\hline PLMN_BOVIN & Plasminogen & PLG & $\begin{array}{l}\text { Biological regulation/localization/ } \\
\text { Metabolic process/Response to stimulus }\end{array}$ & $\begin{array}{l}\text { Binding/Catalytic activity/ } \\
\text { Enzyme regulator activity/ } \\
\text { Receptor activity }\end{array}$ \\
\hline F1MYN5_BOVIN & Fibulin-1 & FBLN1 & Cellular process/Developmental process & Binding \\
\hline F1MNV5_BOVIN & Kininogen-1 & KNG1 & & \\
\hline EF1A1_BOVIN & Elongation factor 1-alpha 1 & EEF1A1 & Biological regulation/Metabolic process & $\begin{array}{l}\text { Binding/Catalytic activity/ } \\
\text { Translation regulator activity }\end{array}$ \\
\hline ITAV_BOVIN & Integrin alpha-V & ITGAV & Biological adhesion & \\
\hline F1MK44_BOVIN & Integrin alpha-5 & ITGA5 & & \\
\hline TTHY_BOVIN & Transthyretin & $T T R$ & localization & Transporter activity \\
\hline F1MC45_BOVIN & $\begin{array}{l}\text { Complement factor } \mathrm{H} \\
\text { (Fragment) }\end{array}$ & $\mathrm{CFH}$ & & \\
\hline J9QD97_BOVIN & Periostin variant 9 & & & \\
\hline ACTS_BOVIN & Actin, alpha skeletal muscle & ACTA1 & $\begin{array}{l}\text { Cellular component organization or } \\
\text { biogenesis/Cellular process/ } \\
\text { Developmental process/localization }\end{array}$ & Structural molecule activity \\
\hline E1B9K1_BOVIN & Polyubiquitin-C & UBC & & \\
\hline A7YWRO_BOVIN & Apolipoprotein E & APOE & & \\
\hline FA9_BOVIN & Coagulation factor IX & F9 & $\begin{array}{l}\text { Apoptotic process/Biological } \\
\text { regulation/Developmental process/ } \\
\text { Immune system process/ localization/ } \\
\text { Metabolic process/Multicellular } \\
\text { organismal process/Response to } \\
\text { stimulus }\end{array}$ & $\begin{array}{l}\text { Binding/Catalytic activity/ } \\
\text { Enzyme regulator activity/ } \\
\text { Receptor activity }\end{array}$ \\
\hline COMP_BOVIN & $\begin{array}{l}\text { Cartilage oligomeric matrix } \\
\text { protein }\end{array}$ & COMP & & \\
\hline
\end{tabular}


Table 1 List of the common proteins identified in exosomes of ICAR cultured at $1 \% \mathrm{O}_{2}$ and at $8 \% \mathrm{O}_{2}$ (Continued)

\begin{tabular}{|c|c|c|c|c|}
\hline K2C80_BOVIN & Keratin, type II cytoskeletal 80 & KRT80 & $\begin{array}{l}\text { Cellular component organization or } \\
\text { biogenesis/Cellular process/ } \\
\text { Developmental process }\end{array}$ & Structural molecule activity \\
\hline TRFE_BOVIN & Serotransferrin & TF & localization/Metabolic process & Catalytic activity \\
\hline K4JDR8_BOVIN & Alpha-2-macroglobulin variant 5 & $\mathrm{~A} 2 \mathrm{M}$ & & \\
\hline Q32P72_BOVIN & $\mathrm{CP}$ protein (Fragment) & $\mathrm{CP}$ & & \\
\hline J9ZW47_BOVIN & Integrin beta & & & \\
\hline F1MM86_BOVIN & Complement component C6 & $\mathrm{C} 6$ & & \\
\hline E1BI02_BOVIN & Fibromodulin & FMOD & & \\
\hline VNN1_BOVIN & Pantetheinase & VNN1 & $\begin{array}{l}\text { Biological adhesion/Cellular process/ } \\
\text { Metabolic process }\end{array}$ & Catalytic activity \\
\hline G3X807_BOVIN & Histone H4 (Fragment) & & $\begin{array}{l}\text { Cellular component organization or } \\
\text { biogenesis/Cellular process/Metabolic } \\
\text { process }\end{array}$ & Binding \\
\hline MOT1_BOVIN & Monocarboxylate transporter 1 & SLC16A1 & Cellular process/localization & Transporter activity \\
\hline TF_BOVIN & Tissue factor & F3 & $\begin{array}{l}\text { Biological regulation/Cellular process/ } \\
\text { Response to stimulus }\end{array}$ & Binding/Receptor activity \\
\hline HS71L_BOVIN & $\begin{array}{l}\text { Heat shock } 70 \mathrm{kDa} \text { protein } \\
\text { 1-like }\end{array}$ & HSPA1L & Metabolic process/Response to stimulus & \\
\hline Q3ZCA7_BOVIN & $\begin{array}{l}\text { Guanine nucleotide binding } \\
\text { protein (G protein), alpha } \\
\text { inhibiting activity polypeptide } 3\end{array}$ & GNAI3 & $\begin{array}{l}\text { Biological regulation/Cellular process/ } \\
\text { Metabolic process/Response to stimulus }\end{array}$ & Binding/Catalytic activity \\
\hline IDHC_BOVIN & $\begin{array}{l}\text { Isocitrate dehydrogenase } \\
\text { [NADP] cytoplasmic }\end{array}$ & $\mathrm{IDH} 1$ & & \\
\hline Q1PBC8_BOVIN & CD14 (Fragment) & & & \\
\hline F1MJJ8_BOVIN & Radixin (Fragment) & RDX & & \\
\hline IF4A2_BOVIN & Eukaryotic initiation factor $4 \mathrm{~A}-\|$ & EIF4A2 & Biological regulation/Metabolic process & $\begin{array}{l}\text { Binding/Catalytic activity/ } \\
\text { Translation regulator activity }\end{array}$ \\
\hline C1QB_BOVIN & $\begin{array}{l}\text { Complement } \mathrm{C} 1 \mathrm{q} \\
\text { subcomponent subunit } \mathrm{B}\end{array}$ & $\mathrm{C} 1 \mathrm{QB}$ & & \\
\hline A6QPD4_BOVIN & LOC790886 protein & LOC790886 & & \\
\hline CTL2_BOVIN & Choline transporter-like protein 2 & SLC44A2 & localization & Transporter activity \\
\hline HPCL1_BOVIN & Hippocalcin-like protein 1 & HPCAL1 & $\begin{array}{l}\text { Cellular process/Multicellularorganismal } \\
\text { process }\end{array}$ & \\
\hline Q24K07_BOVIN & $\begin{array}{l}\text { Vacuolar protein sorting } 11 \\
\text { homolog (S. cerevisiae) }\end{array}$ & VPS11 & & \\
\hline Q5H9M6_BOVIN & Dynein heavy chain (Fragment) & Bv2 & & \\
\hline Q864S1_BOVIN & Cathepsin C (Fragment) & & & \\
\hline Q4ZJSO_BOVIN & $\begin{array}{l}\text { MHC class I antigen } \\
\text { (Fragment) }\end{array}$ & BoLA-N & & \\
\hline Q58CZ4_BOVIN & Flotillin 2 & FLOT2 & & \\
\hline MBL2_BOVIN & Mannose-binding protein C & MBL & & Binding \\
\hline TM214_BOVIN & Transmembrane protein 214 & TMEM214 & & \\
\hline Q8MIR1_BOVIN & $\begin{array}{l}\text { Nicotinic acetylcholine receptor } \\
\text { beta } 2 \text { subunit (Fragment) }\end{array}$ & CHRNB2 & & \\
\hline Q5E9W1_BOVIN & CDC45-like & CDC45L & & \\
\hline
\end{tabular}

Mass spectrometric (with a set FDR of $5 \%$ ) identification of proteins was present in exosomes generated by ICAR cultured at $1 \% \mathrm{O}_{2}$ and at $8 \% \mathrm{O}_{2}$. Data were subjected to ontology and pathway analysis using PANTHER and gene ontology algorithms and classified based on biological process and molecular function

endometrial physiological oxygen levels $\left(8 \% \mathrm{O}_{2} ;[38]\right)$. Moreover, the effect on migration was greater when exposed at $1 \% \mathrm{O}_{2}$ [39]. Interestingly, no relationship between oxygen tension and cell proliferation and apoptosis was observed in this previous study. Differences in cell types may explain this observation. Ito et al. 


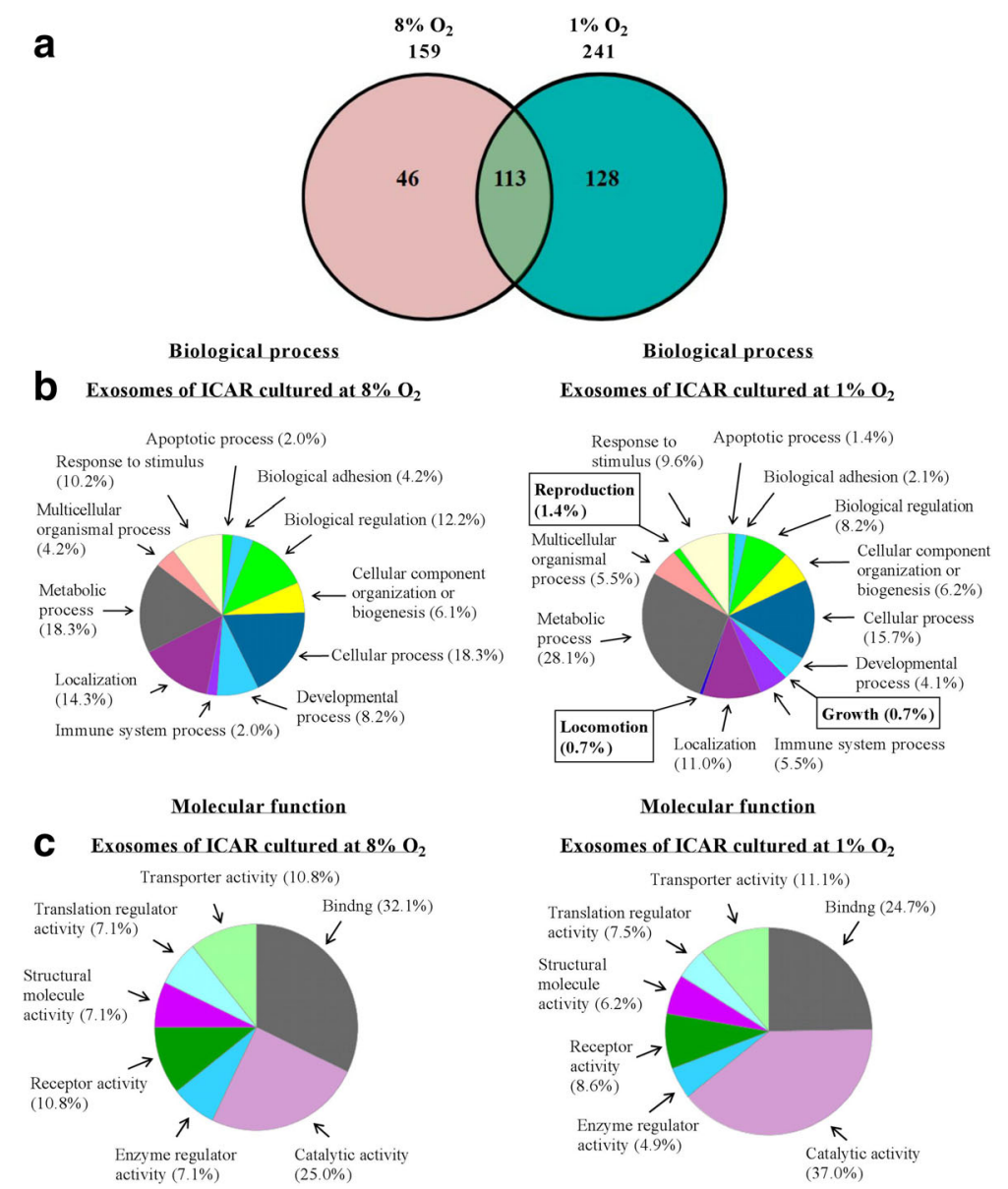

Fig. 5 Proteomic analysis of bovine endometrial ICAR-derived exosomes. Mass spectrometric analyses of ICAR cell-derived exosome proteins. a Representative Venn diagram of common and unique proteins identified by 5600 Triple TOF MS (ABSciex) from exosomes released by ICAR cells at $48 \mathrm{~h}$ at both $8 \% \mathrm{O}_{2}$ and $1 \% \mathrm{O}_{2}$. b The gene ontology classification of ICAR cell-derived exosome proteins, on the basis of their involvement in biological process, identified clusters that are unique to and present only in exosomes of ICAR cultured at $1 \% \mathrm{O}_{2}$ but not those at $8 \% \mathrm{O}_{2}$. These biological processes were: growth (0.7\%), locomotion (0.7\%) and reproduction (1.4\%). c Molecular function (using PANTHER and Gene Ontology algoritnms) of exosome proteins were mostly related to binding and catalytic activity in both ICAR cultured at $1 \% \mathrm{O}_{2}$ and at $8 \% \mathrm{O}_{2}$

described the rate of proliferation of human mesenchymal stem cell (MSCs) was observed to be highest in $5 \%$ $\mathrm{O}_{2}$ and the lowest in $<0.1 \% \mathrm{O}_{2}$ conditions [40]. The MSCs at severely induced hypoxic conditions $(<0.1 \%$ $\mathrm{O}_{2}$ ), showed a decrease in proliferative ability, but were able to maintain viability for at least $48 \mathrm{~h}$ through increased glucose availability, to facilitate the generation of energy. Similar results were obtained from an airway smooth muscle study [41]. Hence, our cells have relatively normal proliferation responses to decreased oxygen tension.

Our study suggests that exosomes can serve as a vector for signaling molecules that harbor a variety of bioactive molecules including proteins at the conceptusendometrial interface and that has the potential to modulate the functions of targeted cells during early pregnancy. Endometrial exosome release may also be modulated during an insult such as infection [42, 43].
In the current study we utilized hypoxia (i.e. $1 \% \mathrm{O}_{2}$ ) as a known modulator of exosome release as documented by alteration to both the number of exosomes released as well as differences in the exosomal content (cargo) [24, 27, 29].

In our study, endometrial cells exposed to $1 \% \mathrm{O}_{2-}$ released $\sim 3.6$ more exosomes relative to the $8 \% \mathrm{O}_{2}$ culture treatment, suggesting that hypoxia modulates cell function, including the release of exosomes. Hypoxia has already been reported to be a stimulus to increase secretion of exosomes by several groups [44-46]. It is also suggested that the protein and RNA content of exosomes can reflect the physiological state of the cell as well as when the cells are in stress condition [47, 48]. However, the initial stress insult that contributed to an alteration of the exosomal content in relation to the functional effects of the subsequent cargo transfer and their role in 
cell-to-cell communication remains unclear. It is possible that exposure to other stressors such as adverse environmental hazards [49-51] will also increase secretion of exosomes and alter composition of the cargo.

The protein content of exosomes from ICAR cells cultured under the $1 \% \mathrm{O}_{2}$ contained unique proteins compared to the contents of the ICAR exosomes cultured at $8 \% \mathrm{O}_{2}$. Our proteomic analyses detected the presence of tetraspanin-6 (TSPAN6), disintegrin and metalloproteinase domain-containing protein 10 (ADAM10) that are only unique to exosomes of ICAR cultured at $1 \% \mathrm{O}_{2}$. These proteins are involved in the biological processes for reproduction. Interestingly, to evaluate TSPAN6, belonging to the transmembrane 4 superfamily that mediate the regulation of signal transduction events, as well as the disintegrin-like metalloproteinase ADAM10 which participates in ectodomain shedding activity could provide great insights into their functional role and regulation that is important for reproduction.

Studies using immunohistochemistry of human placental explants [52] have demonstrated that ADAM10 expression is significantly increased in preeclamptic placentas compared with normal placentas. Up-regulation of ADAM10 could induce placental release of soluble vascular endothelial growth factor receptor-1 (sFlt-1) and this cascade is associated with endothelial dysfunction, suggesting the significant role of oxidative change in preeclamptic placentas. ADAM10 is also a sheddase [53] that could induce CD46 shedding attributed to cell apoptotic processes [54], as well as mediate Ecadherin shedding affecting cellular adhesion and cell migration [55].

Mass spectrometry detection of pantetheinase (VNN1) in exosomes was unique to ICAR cultured at $8 \% \mathrm{O}_{2}$. VNN1 is an enzyme that hydrolyses pantetheine to form pantothenic acid (a precursor of coenzyme A) and the antioxidant cysteamine [56]. VNN1 could promote tissue inflammation through peroxisome proliferator-activated receptor gamma as well as modulate levels of glutathione [57]. It is proposed that VNN1 have innate immune functions and might contribute to tissue injury in endometritis $[58,59]$. VNN1 was also reported being involved in proteolysis and can denature proteins by reducing disulfides [60], suggesting that it may have a role in regulating uterine receptivity for implantation and trophoblast invasion [61].

Mass spectrometry detected kininogen-2 (KNG2) in exosomes generated by ICAR cells cultured at either 1 or $8 \% \mathrm{O}_{2}$. KNG2 is a precursor protein to high molecular weight kininogen, low molecular weight kininogen and bradykinin and the concentration were reported to fluctuate during ovulation, pregnancy, and parturition [62]. Studies also showed that the release of vasoactive bradykinins from high molecular weight kininogen and low molecular weight kininogen are responsible for micro-vascular permeability and vascular growth, which plays an essential role in utero-placental vasculature and angiogenesis, necessary for embryonic and fetal survival [63].

\section{Conclusion}

Our present findings show that ICAR cell function, release of exosomes and exosomal content can be altered when subjected to adverse stimuli. These findings should be expanded to include cells of endometrial epithelial origin, interactions between these cells (i.e. stromal-epithelial crosstalk) and in the presence of common pathophysiological factors associated with reduced fertility (e.g. infectious or inflammatory agents). The identification of unique proteins (by mass spectrometry) in exosomes of ICAR cultured at $1 \% \mathrm{O}_{2}$ compared to $8 \% \mathrm{O}_{2}$ suggests that the cells respond and release proteins encapsulated within the exosomes to signal the environment in which they live. It is hoped that identification of unique proteins in exosomes following stimulation by factors affecting the physiological condition of cows may lead to novel targets for manipulation to aid fertility. Moreover, investigations into the release, uptake and content of exosomes may offer the opportunity to evaluate maternal-fetal crosstalk.

\section{Abbreviations}

ADAM10: Metalloproteinase domain-containing protein 10;

DTT: Dithiothreitol; FDR: False discovery rate; ICAR: Intercaruncular stromal cell; KNG2: Kininogen-2; LDH: Lactate dehydrogenase;

MS/MS: Mass spectrometry/mass spectrometry; PANTHER: Protein analysis through evolutionary relationships; PBS: Phosphate buffered saline; $\mathrm{PGF}_{2 a}$ : Prostaglandin $\mathrm{F}_{2 a}$ i PVDF: Polyvinylidene fluoride;

RIPA: Radioimmunoprecipitation assay buffer; RWD: Relative wound density; sFLT-1: Soluble vascular endothelial growth factor receptor-1; TSPAN6: Tetraspanin-6; VNN1: Pantetheinase

\section{Acknowledgments \\ The authors acknowledge the assistance of Dr. Jamie Riches and Dr. Rachel Hancock of the Central Analytical Research Facility, Institute for Future Environments, Queensland University of Technology (QUT) for the electron microscope analyses. \\ We also thank our colleagues at DairyNZ for their helpful insights. YQ Koh is supported by a student scholarship from a partnership fund (DRCX1302) between the New Zealand Ministry of Business, Innovation and Employment and New Zealand dairy farmers through DairyNZ Inc. CS holds a research fellowship at The University of Queensland Centre for Clinical Research, Brisbane, Australia. GER was in receipt of an NMHRC Principal Research Fellowship. These studies were funded in part by the Australian Research Council, Therapeutic Innovation Australian and National Collaborative Research Infrastructure Strategy.}

Funding

Australian Research Council and a partnership fund (DRCX1302) between the New Zealand Ministry of Business, Innovation and Employment and New Zealand dairy farmers through DairyNZ Inc. 


\section{Availability of data and materials}

The datasets during and/or analyzed during the current study available from the corresponding author on reasonable request.

\section{Authors' contributions}

YQK performed the study, collected and interpreted data performing statistical analysis and wrote the manuscript. YQK, SR, HNP and KV performed mass spectrometry analyses and reviewed the data generated. YQK, CS, HNP, GER and MDM were responsible for the study concept and participated in designing the study and interpreted data. CS, GER, HNP, MDM revised and approved the final version of manuscript.

\section{Competing interests}

The authors declare that they have no competing interests.

\section{Consent for publication}

Not applicable.

\section{Ethics approval and consent to participate}

Not applicable.

Received: 21 September 2016 Accepted: 25 October 2016 Published online: 09 November 2016

\section{References}

1. Banu SK, Arosh JA, Chapdelaine P, Fortier MA. Expression of prostaglandin transporter in the bovine uterus and fetal membranes during pregnancy. Biol Reprod. 2005;73:230-6.

2. Verduzco A, Fecteau G, Lefebvre R, Smith LC, Murphy BD. Expression of steroidogenic proteins in bovine placenta during the first half of gestation. Reprod Fertil Dev. 2012;24:392-404.

3. Mansouri-Attia N, Aubert J, Reinaud P, Giraud-Delville C, Taghouti G, Galio L, Everts RE, Degrelle S, Richard C, Hue I, et al. Gene expression profiles of bovine caruncular and intercaruncular endometrium at implantation. Physiol Genomics. 2009;39:14-27.

4. Arosh JA, Banu SK, Chapdelaine P, Fortier MA. Temporal and tissue-specific expression of prostaglandin receptors EP2, EP3, EP4, FP, and cyclooxygenases 1 and 2 in uterus and fetal membranes during bovine pregnancy. Endocrinology. 2004;145:407-17.

5. Gray CA, Bartol FF, Tarleton BJ, Wiley AA, Johnson GA, Bazer FW, Spencer TE. Developmental biology of uterine glands. Biol Reprod. 2001;65:1311-23.

6. Ashley RL, Antoniazzi AQ, Anthony RV, Hansen TR. The chemokine receptor CXCR4 and its ligand CXCL12 are activated during implantation and placentation in sheep. Reprod Biol Endocrinol. 2011;9:148,

7. Bauersachs $\mathrm{S}$, Wolf E. Immune aspects of embryo-maternal cross-talk in the bovine uterus. J Reprod Immunol. 2013:97:20-6.

8. Asselin E, Drolet P, Fortier MA. In vitro response to oxytocin and interferonTau in bovine endometrial cells from caruncular and inter-caruncular areas. Biol Reprod. 1998;59:241-7.

9. Turner ML, Cronin JG, Healey GD, Sheldon IM. Epithelial and stromal cells of bovine endometrium have roles in innate immunity and initiate inflammatory responses to bacterial lipopeptides in vitro via Toll-like receptors TLR2, TLR1, and TLR6. Endocrinology. 2014;155:1453-65.

10. Arnold JT, Kaufman DG, Seppala M, Lessey BA. Endometrial stromal cells regulate epithelial cell growth in vitro: a new co-culture model. Hum Reprod. 2001;16:836-45.

11. Okuda K, Kasahara Y, Murakami S, Takahashi H, Woclawek-Potocka I, Skarzynski DJ. Interferon-tau blocks the stimulatory effect of tumor necrosis factor-alpha on prostaglandin F2alpha synthesis by bovine endometrial stromal cells. Biol Reprod. 2004;70:191-7.

12. Asselin $E$, Goff AK, Bergeron H, Fortier MA. Influence of sex steroids on the production of prostaglandins F2 alpha and E2 and response to oxytocin in cultured epithelial and stromal cells of the bovine endometrium. Biol Reprod. 1996;54:371-9.

13. Krishnaswamy N, Chapdelaine P, Tremblay JP, Fortier MA. Development and characterization of a simian virus 40 immortalized bovine endometrial stromal cell line. Endocrinology. 2009;150:485-91.

14. $\mathrm{Ng} \mathrm{YH}$, Rome $\mathrm{S}$, Jalabert $\mathrm{A}$, Forterre $\mathrm{A}$, Singh $\mathrm{H}$, Hincks $\mathrm{CL}$, Salamonsen LA. Endometrial exosomes/microvesicles in the uterine microenvironment: a new paradigm for embryo-endometrial cross talk at implantation. PLoS One. 2013;8:e58502.

15. Ruiz-Gonzalez I, Xu J, Wang X, Burghardt RC, Dunlap KA, Bazer FW. Exosomes, endogenous retroviruses and toll-like receptors: pregnancy recognition in ewes. Reproduction. 2015;149:281-91.

16. Cleys ER, Halleran JL, McWhorter E, Hergenreder J, Enriquez VA, da Silveira JC, Bruemmer JE, Winger QA, Bouma GJ. Identification of microRNAs in exosomes isolated from serum and umbilical cord blood, as well as placentomes of gestational day 90 pregnant sheep. Mol Reprod Dev. 2014;81:983-93.

17. Burns G, Brooks K, Wildung M, Navakanitworakul R, Christenson LK, Spencer TE. Extracellular vesicles in luminal fluid of the ovine uterus. PLoS One. 2014;9:e90913.

18. Sohel MM, Hoelker M, Noferesti SS, Salilew-Wondim D, Tholen E, Looft C, Rings F, Uddin MJ, Spencer TE, Schellander K, Tesfaye D. Exosomal and non-exosomal transport of extra-cellular microRNAs in follicular fluid: implications for Bovine Oocyte Developmental Competence. PLoS One. 2013:8:e78505.

19. van der Pol E, Boing AN, Harrison P, Sturk A, Nieuwland R. Classification, functions, and clinical relevance of extracellular vesicles. Pharmacol Rev. 2012;64:676-705.

20. Simons M, Raposo G. Exosomes-vesicular carriers for intercellular communication. Curr Opin Cell Biol. 2009;21:575-81.

21. Gupta S, Knowlton AA. HSP60 trafficking in adult cardiac myocytes: role of the exosomal pathway. Am J Physiol Heart Circ Physiol. 2007;292:H3052-3056.

22. Orriss IR, Knight GE, Utting JC, Taylor SE, Burnstock G, Arnett TR. Hypoxia stimulates vesicular ATP release from rat osteoblasts. J Cell Physiol. 2009;220:155-62.

23. Wysoczynski M, Ratajczak MZ. Lung cancer secreted microvesicles: underappreciated modulators of microenvironment in expanding tumors. Int J Cancer. 2009;125:1595-603.

24. King HW, Michael MZ, Gleadle JM. Hypoxic enhancement of exosome release by breast cancer cells. BMC Cancer. 2012;12:421.

25. Maltepe E, Saugstad OD. Oxygen in health and disease: regulation of oxygen homeostasis-clinical implications. Pediatr Res. 2009;65:261-8.

26. Mallard EC, Rees S, Stringer M, Cock ML, Harding R. Effects of chronic placental insufficiency on brain development in fetal sheep. Pediatr Res. 1998;43:262-70

27. Park JE, Tan HS, Datta A, Lai RC, Zhang H, Meng W, Lim SK, Sze SK. Hypoxic tumor cell modulates its microenvironment to enhance angiogenic and metastatic potential by secretion of proteins and exosomes. Mol Cell Proteomics. 2010;9:1085-99.

28. Salomon C, Kobayashi M, Ashman K, Sobrevia L, Mitchell MD, Rice GE. Hypoxia-induced changes in the bioactivity of cytotrophoblast-derived exosomes. PLoS One. 2013;8:e79636.

29. Onogi $A$, Naruse $K$, Sado T, Tsunemi $T$, Shigetomi $H$, Noguchi $T$, Yamada $Y$, Akasaki M, Oi H, Kobayashi H. Hypoxia inhibits invasion of extravillous trophoblast cells through reduction of matrix metalloproteinase (MMP)-2 activation in the early first trimester of human pregnancy. Placenta. 2011;32:665-70.

30. Fortier MA, Guilbault LA, Grasso F. Specific properties of epithelial and stromal cells from the endometrium of cows. J Reprod Fertil. 1988;83:239-48.

31. Salomon C, Ryan J, Sobrevia L, Kobayashi M, Ashman K, Mitchell M, Rice GE. Exosomal signaling during hypoxia mediates microvascular endothelial cell migration and vasculogenesis. PLoS One. 2013;8:e68451.

32. Kobayashi M, Salomon C, Tapia J, Illanes SE, Mitchell MD, Rice GE. Ovarian cancer cell invasiveness is associated with discordant exosomal sequestration of Let-7 miRNA and miR-200. J Transl Med. 2014;12:4.

33. Salomon C, Torres MJ, Kobayashi M, Scholz-Romero K, Sobrevia L, Dobierzewska A, Illanes SE, Mitchell MD, Rice GE. A gestational profile of placental exosomes in maternal plasma and their effects on endothelial cell migration. PLos One. 2014;9(6):e98667.

34. Brinkman DL, Jia X, Potriquet J, Kumar D, Dash D, Kvaskoff D, Mulvenna J. Transcriptome and venom proteome of the box jellyfish Chironex fleckeri. BMC Genomics. 2015;16:407.

35. Vaswani K, Ashman K, Reed S, Salomon C, Sarker S, Arraztoa JA, PerezSepulveda A, Illanes SE, Kvaskoff D, Mitchell MD, Rice GE. Applying SWATH mass spectrometry to investigate human cervicovaginal fluid during the menstrual cycle. Biol Reprod. 2015;93:39.

36. Rappsilber J, Ishihama Y, Mann M. Stop and go extraction tips for matrixassisted laser desorption/ionization, nanoelectrospray, and LC/MS sample pretreatment in proteomics. Anal Chem. 2003;75:663-70. 
37. Thomas PD, Campbell MJ, Kejariwal A, Mi H, Karlak B, Daverman R, Diemer K, Muruganujan A, Narechania A. PANTHER: a library of protein families and subfamilies indexed by function. Genome Res. 2003;13:2129-41.

38. Gahlenbeck H, Frerking H, Rathschlag-Schaefer AM, Bartels H. Oxygen and carbon dioxide exchange across the cow placenta during the second part of pregnancy. Respir Physiol. 1968;4:119-31.

39. Ng CT, Biniecka M, Kennedy A, McCormick J, Fitzgerald O, Bresnihan B, Buggy D, Taylor CT, O'Sullivan J, Fearon U, Veale DJ. Synovial tissue hypoxia and inflammation in vivo. Ann Rheum Dis. 2010;69:1389-95.

40. Ito A, Aoyama T, Yoshizawa M, Nagai M, Tajino J, Yamaguchi S, lijima H, Zhang $X$, Kuroki $H$. The effects of short-term hypoxia on human mesenchymal stem cell proliferation, viability and p16(INK4A) mRNA expression: Investigation using a simple hypoxic culture system with a deoxidizing agent. J Stem Cells Regen Med. 2015;11:25-31.

41. Cogo A, Napolitano G, Michoud MC, Barbon DR, Ward M, Martin JG. Effects of hypoxia on rat airway smooth muscle cell proliferation. J Appl Physiol (1985). 2003;94:1403-9.

42. Harp D, Driss A, Mehrabi S, Chowdhury I, Xu W, Liu D, Garcia-Barrio M, Taylor RN, Gold B, Jefferson S, et al. Exosomes derived from endometriotic stromal cells have enhanced angiogenic effects in vitro. Cell Tissue Res. 2016:365:187-96.

43. Nudel K, Massari P, Genco CA. Neisseria gonorrhoeae Modulates Cell Death in Human Endocervical Epithelial Cells through Export of ExosomeAssociated CIAP2. Infect Immun. 2015;83:3410-7.

44. Lee SM, Romero R, Lee YJ, Park IS, Park CW, Yoon BH. Systemic inflammatory stimulation by microparticles derived from hypoxic trophoblast as a model for inflammatory response in preeclampsia. Am J Obstet Gynecol. 2012;207(4):337.e1-8.

45. Kucharzewska P, Christianson HC, Welch JE, Svensson KJ, Fredlund E, Ringner M, Morgelin M, Bourseau-Guilmain E, Bengzon J, Belting M. Exosomes reflect the hypoxic status of glioma cells and mediate hypoxiadependent activation of vascular cells during tumor development. Proc Natl Acad Sci U S A. 2013;110:7312-7.

46. Sano S, Izumi Y, Yamaguchi T, Yamazaki T, Tanaka M, Shiota M, Osada-Oka M, Nakamura Y, Wei M, Wanibuchi $H$, et al. Lipid synthesis is promoted by hypoxic adipocyte-derived exosomes in 3 T3-L1 cells. Biochem Biophys Res Commun. 2014;445:327-33.

47. Belting $\mathrm{M}_{1}$ Christianson HC. Role of exosomes and microvesicles in hypoxiaassociated tumour development and cardiovascular disease. J Intern Med. 2015;278:251-63.

48. de Jong OG, Verhaar MC, Chen Y, Vader P, Gremmels H, Posthuma G, Schiffelers RM, Gucek M, van Balkom BW: Cellular stress conditions are reflected in the protein and RNA content of endothelial cell-derived exosomes. J Extracell Vesicles. 2012;1. http://www. journalofextracellularvesicles.net/index.php/jev/article/view/18396.

49. Alvarez-Erviti L, Seow Y, Schapira AH, Gardiner C, Sargent IL, Wood MJ, Cooper JM. Lysosomal dysfunction increases exosome-mediated alpha-synuclein release and transmission. Neurobiol Dis. 2011;42:360-7.

50. Fevrier B, Vilette D, Archer F, Loew D, Faigle W, Vidal M, Laude H, Raposo G. Cells release prions in association with exosomes. Proc Natl Acad Sci U S A. 2004;101:9683-8.

51. Pan-Montojo F, Reichmann H. Considerations on the role of environmental toxins in idiopathic Parkinson's disease pathophysiology. Transl Neurodegener. 2014;3:10.

52. Zhao S, Gu Y, Fan R, Groome L, Cooper D, Wang Y. Proteases and sFlt-1 release in the human placenta. Placenta. 2010;31:512-8.

53. Bouillot S, Tillet E, Carmona G, Prandini MH, Gauchez AS, Hoffmann P, Alfaidy N, Cand F, Huber P. Protocadherin-12 cleavage is a regulated process mediated by ADAM10 protein: evidence of shedding up-regulation in pre-eclampsia. J Biol Chem. 2011;286:15195-204.

54. Hakulinen J, Keski-Oja J. ADAM10-mediated release of complement membrane cofactor protein during apoptosis of epithelial cells. J Biol Chem. 2006;281:21369-76.

55. Maretzky T, Reiss K, Ludwig A, Buchholz J, Scholz F, Proksch E, de Strooper B, Hartmann D, Saftig P. ADAM10 mediates E-cadherin shedding and regulates epithelial cell-cell adhesion, migration, and beta-catenin translocation. Proc Natl Acad Sci U S A. 2005;102:9182-7.

56. Martin F, Malergue F, Pitari G, Philippe JM, Philips S, Chabret C, Granjeaud S, Mattei MG, Mungall AJ, Naquet P, Galland F. Vanin genes are clustered (human 6q22-24 and mouse 10A2B1) and encode isoforms of pantetheinase ectoenzymes. Immunogenetics. 2001;53:296-306.
57. Dammanahalli KJ, Stevens S, Terkeltaub R. Vanin-1 pantetheinase drives smooth muscle cell activation in post-arterial injury neointimal hyperplasia. PLoS One. 2012;7:e39106.

58. Hayes MA, Quinn BA, Lillie BN, Cote O. Changes in various endometrial proteins during cloprostenol-induced failure of early pregnancy in mares. Anim Reprod. 2012;9:723-41.

59. Berruyer C, Martin FM, Castellano R, Macone A, Malergue F, Garrido-Urbani S, Millet V, Imbert J, Dupre S, Pitari G, et al. Vanin-1-/- mice exhibit a glutathione-mediated tissue resistance to oxidative stress. Mol Cell Biol. 2004;24:7214-24.

60. Kaskow BJ, Proffitt JM, Blangero J, Moses EK, Abraham LJ. Diverse biological activities of the vascular non-inflammatory molecules - the Vanin pantetheinases. Biochem Biophys Res Commun. 2012;417:653-8.

61. Mullen MP, Elia G, Hilliard M, Parr MH, Diskin MG, Evans AC, Crowe MA. Proteomic characterization of histotroph during the preimplantation phase of the estrous cycle in cattle. J Proteome Res. 2012;11:3004-18.

62. Karkkainen T, Hamberg U. Kininogen as a pregnancy-associated plasma protein. Adv Exp Med Biol. 1986;198(Pt A):167-72.

63. Vonnahme KA, Fernando SC, Ross JW, Ashworth MD, DeSilva U, Malayer JR, Geisert RD. Porcine endometrial expression of kininogen, factor XII, and plasma kallikrein in cyclic and pregnant gilts. Biol Reprod. 2004;70:132-8

\section{Submit your next manuscript to BioMed Central and we will help you at every step:}

- We accept pre-submission inquiries

- Our selector tool helps you to find the most relevant journal

- We provide round the clock customer support

- Convenient online submission

- Thorough peer review

- Inclusion in PubMed and all major indexing services

- Maximum visibility for your research

Submit your manuscript at www.biomedcentral.com/submit
Biomed Central 